\title{
Article \\ Cerebral Vein Thrombosis in the Antiphospholipid Syndrome: Analysis of a Series of 27 Patients and Review of the Literature
}

\author{
Alba Jerez-Lienas 1,2, Alexis Mathian ${ }^{3}$, Jenifer Aboab ${ }^{3}$, Isabelle Crassard ${ }^{4}$, Miguel Hie ${ }^{3}$, Fleur Cohen-Aubart ${ }^{3}$, \\ Julien Haroche ${ }^{3}$, Denis Wahl ${ }^{5}$, Ricard Cervera ${ }^{1, *}$ and Zahir Amoura ${ }^{3}$ \\ 1 Department of Autoimmune Diseases, Universitat de Barcelona, Hospital Clínic, 08036 Barcelona, Spain; \\ ajerez@mutuaterrassa.cat \\ 2 Systemic Autoimmune Diseases Unit, Department of Internal Medicine, Universitat de Barcelona, \\ Hospital Universitari Mútua de Terrassa, 08221 Terrassa, Spain \\ 3 French National Referral Center for Systemic Lupus Erythematosus, Antiphospholipid Antibody Syndrome \\ and Other Autoimmune Disorders, Service de Médecine Interne 2, Institut E3M, Inserm UMRS, \\ Centre d'Immunologie et des Maladies Infectieuses (CIMI-Paris), Assistance Publique-Hôpitaux de \\ Paris (APHP), Groupement Hospitalier Pitié-Salpêtrière, Sorbonne Université, 75013 Paris, France; \\ alexis.mathian@aphp.fr (A.M.); jenifer.aboab@aphp.fr (J.A.); miguel.hie@aphp.fr (M.H.); \\ fleur.cohen@aphp.fr (F.C.-A.); julien.haroche@aphp.fr (J.H.); zahir.amoura@aphp.fr (Z.A.) \\ 4 Department of Neurology, Hôpital Lariboisière, 75010 Paris, France; isabelle.crassard@lrb.aphp.fr \\ 5 Department of Vascular Medicine, Referral Center for Rare Vascular Diseases, Centre Hospitalier Régional \\ Universitaire de Nancy, 54500 Vandoeuvre-lès-Nancy, France; d.wahl@chru-nancy.fr \\ * Correspondence: rcervera@clinic.cat
}

Citation: Jerez-Lienas, A.; Mathian, A.; Aboab, J.; Crassard, I.; Hie, M.; Cohen-Aubart, F.; Haroche, J.; Wahl, D.; Cervera, R.; Amoura, Z. Cerebral Vein Thrombosis in the Antiphospholipid Syndrome: Analysis of a Series of 27 Patients and Review of the Literature. Brain Sci. 2021, 11, 1641. https://doi.org/ 10.3390/brainsci11121641

Academic Editor:

Ferdinando Nicoletti

Received: 31 October 2021

Accepted: 6 December 2021

Published: 13 December 2021

Publisher's Note: MDPI stays neutral with regard to jurisdictional claims in published maps and institutional affiliations.

Copyright: (c) 2021 by the authors. Licensee MDPI, Basel, Switzerland. This article is an open access article distributed under the terms and conditions of the Creative Commons Attribution (CC BY) license (https:// creativecommons.org/licenses/by/ $4.0 /)$.
Abstract: (1) Background: The Antiphospholipid Syndrome (APS) is a systemic autoimmune disorder characterized by arterial and/or venous thrombosis, pregnancy morbidity and raised titers of antiphospholipid antibodies. Cerebral vein thrombosis (CVT) is a rare form of cerebrovascular accident and an uncommon APS manifestation; the information in the literature about this feature consists of case reports and small case series. Our purpose is to describe the particular characteristics of CVT when occurs as part of the APS and compare our series with the patients published in the literature. (2) Methods: We conducted a retrospective observational study collecting data from medical records in three referral centers for APS and CVT, and a systematic review of the literature for CVT cases in APS patients. (3) Results: Twenty-seven APS patients with CVT were identified in our medical records, the majority of them diagnosed as primary APS and with the CVT being the first manifestation of the disease; additional risk factors for thrombosis were identified. The review of the literature yielded 86 cases, with similar characteristics as those of our retrospective series. (4) Conclusions: To our knowledge, our study is the largest CVT series in APS patients published to date, providing a unique point of view in this rare thrombotic manifestation.

Keywords: antiphospholipid syndrome; antiphospholipid antibodies; cerebral vein thrombosis; intracranial sinus thrombosis

\section{Introduction}

The antiphospholipid syndrome (APS) is a systemic autoimmune disorder characterized by arterial and/or venous thromboses, pregnancy morbidity and raised titers of antiphospholipid antibodies (aPL) [1,2]. It is considered to be the most common acquired thrombophilia. Thrombotic events in these patients consist in deep vein thrombosis (32\%), stroke $(13 \%)$, superficial thrombophlebitis $(9 \%)$, pulmonary embolism $(9 \%)$ and transient ischemic attack $(7 \%)$, among other clinical manifestations. Stroke is the most frequent arterial thrombosis [3].

Cerebral vein thrombosis (CVT) is the thrombotic occlusion of a cerebral sinus or parenchymal vein, which occurs predominantly in young women (median age, 39 years; female/male ratio, 3/1) [4]. It is a rare disease, as it represents only $0.5-1 \%$ of the cerebral vascular accidents [5] and has an estimated incidence of 1.32 per 100.000 person-years [6]. 
The clinical picture in a patient presenting with CVT will differ according to the location of the thrombosis. When it affects a cerebral parenchymal vein, it induces a cytotoxic and vasogenic edema that is more prominent than in an arterial stroke, and it can evolve into a hemorrhagic stroke due to high pressure in the veins. If the thrombosis affects a cerebral sinus vein, it diminishes the cerebrospinal fluid absorption, which may lead to intracranial hypertension [7].

Many risk factors and causes have been related to the development of CVT; however, in $12.5 \%$ of adult patients with CVT no cause is identified after a thorough search [4]. Conversely, in more than half of patients with CVT more than one risk factor is identified, which encourages a methodical clinical search for risk factors, even in those patients who have an obvious cause [4], as it may modify the prognosis and clinical management. The CVT etiology has changed in developed countries since the development of antibiotics, as it used to be mainly due to an infectious disease [4,8-10], but currently thrombophilia (either genetic or acquired) and oral contraceptives seem to be the most common risk factors. Nowadays, thanks to the advanced imaging techniques, more cases of CVT are diagnosed, even in the setting of paucisymptomatic patients, expanding our knowledge on associated causes. The use of anticoagulant treatments has also improved its prognosis.

Currently, the most frequent etiology of CVT is genetic thrombophilia, which can be identified in $20-30 \%$ of patients. The most commonly found thrombophilia are factor V Leiden mutation (15-17\%) and prothrombin gene mutation G20210A (10-12\%) [11]. In a series of 121 patients with CVT, hyperhomocystinemia was identified in $20 \%$ of the cases [12]. In female patients, oral contraceptives are a prominent cause, frequently associated with other risk factors [13].

As for systemic inflammatory diseases, in the International Study on Cerebral Vein and Dural Sinus Thrombosis (ISCVT) series of 624 patients [4], the underlying cause was APS in $5.9 \%$ of patients, inflammatory bowel disease in $1.6 \%$, Behçet disease in $1 \%$ and systemic lupus erythematosus (SLE) in 1\% of cases. In the 1000 APS patient's series of Cervera et al. [3], only 7 patients had a CVT. Therefore, CVT is an uncommon manifestation in APS patients, which makes it difficult to collect medical information in order to expand our knowledge in this topic; the information available in the literature is scarce and most of the published studies are case reports or short case series.

On this study, we conducted a retrospective observational study in three university care referral center hospitals in order to describe the clinical features, diagnostic procedures, therapeutic options, outcome and follow-up characteristics of APS patients with CVT. We also conducted a review of the literature to gather the clinical features, diagnostic procedures, therapeutic options, outcome and follow-up characteristics of the CVT cases in APS patients published in the literature, and compared them to our retrospective series, in order to evaluate the homogeneity of their clinical characteristics.

\section{Materials and Methods}

We conducted a retrospective study in three main referral hospitals, collecting data from patients with CVT associated to APS: Service de Médecine Interne 2 of Hôpital PitiéSalpêtrière, Paris, France (French national referral center for SLE and APS patients); the Department of Neurology of Hôpital Lariboisière, Paris, France (referral center for rare vascular diseases of the brain and the eye (CERVCO)) and the Department of Autoimmune Diseases of Hospital Clínic, Barcelona, Catalonia, Spain (referral center for autoimmune diseases). The search for clinical cases was made through review of the medical database of each department, from January 1986 to July 2016 in the Service de Médecine Interne 2 Hôpital Pitié-Salpêtrière, from September 1997 to June 2013 in the Department of Neurology of Hôpital Lariboisière and from January 1985 to September 2021 in the Department of Autoimmune Diseases of Hospital Clínic.

We included patients with CVT in association with APS, according to the following criteria: The diagnosis of CVT was based on clinical suspicion due to a compatible clinical picture and confirmed with a brain imaging technique (computed tomography scan 
(CT scan) or magnetic resonance imaging (MRI), with or without intravenous contrast) with typical abnormalities [14,15]. In all cases, the diagnosis of CVT was confirmed by a neuroradiologist.

The diagnosis of APS was based on the available criteria at the time of the patient evaluation in the referral hospital. Accordingly, patients diagnosed with APS prior to 2006 fulfilled the Sapporo criteria [16], while subsequent cases fulfilled the Sydney criteria for APS [17]. Besides the thromboembolic event of the CVT, patients had to present the following laboratory criteria:

- Sapporo criteria (before 2006): two positive results determined 6 weeks apart for anticardiolipin antibodies (aCL) at high or medium titer (or $>99$ th percentile), IgG or IgM isotypes, or the presence of circulating lupus anticoagulant (LA).

- Sydney criteria (after 2006): two positive results, 12 weeks apart, for aCL, IgG or IgM isotypes, at titer > $40 \mathrm{GPL} / \mathrm{MPL}$ or $>99$ th percentile; or the presence of anti-beta-2glycoprotein antibodies (aß2GPI) at $>99$ th percentile; or the presence of circulating lupus anticoagulant (LA).

- All patients underwent a laboratory search for aPL on their referral hospital, and LA presence was confirmed by a second test, as recommended by the international guidelines.

According to the APS criteria, we excluded all patients with CVT whose laboratory findings suggestive of APS were not available for 5 years after the thrombotic event.

A systematic review of the literature was performed in order to obtain all available information on CVT and APS, as well as to collect all cases of CVT in association to APS. The search for relevant articles was conducted using Medline on the PubMed web page, with the following keywords (MeSH terms) composed formula: ["Antiphospholipid Syndrome" OR "Antibodies, Antiphospholipid"] AND "Intracranial Thrombosis". In addition, some articles were included by review of references from selected articles and by manual search. Last access to the web was on September 2021. We selected articles in English, French, Spanish and German, from January 1983 to September 2021.

Articles were selected if their main topic was CVT, APS or the association of both conditions, including reported cases of patients with CVT associated to APS. To be included in the case series of the literature, the reported clinical cases had to fulfill the same inclusion criteria applied to our case series, as described above. Cases lacking the following information in the article description were excluded: APS classification, previous APS manifestations, clinical signs and symptoms leading to the diagnosis of the CVT, aPL profile, CVT location, as well as associated intra- or extra-parenchymal complications, treatment and outcome of the acute injury. Clinical cases of patients younger than 13 years of age were excluded.

All clinical data from the patients in our retrospective series were collected from the medical reports. At the time of CVT, the following data were gathered: epidemiologic information (age, gender), clinical picture, imaging technique leading to the diagnosis, CVT location and extension (CVT was considered extended if affecting more than one sinus vein), presence of intra- or extra-parenchymal complications (venous infarction or intracranial bleeding), presence of intracranial hypertension (diagnosed by observation of papilledema on fundoscopy), treatment given on the acute phase and duration of the hospital admission. The diagnostic delay was determined by the time between the onset of the symptoms and the CVT diagnosis. Depending on the diagnostic delay, three groups of clinical presentation were established: the clinical presentation was considered acute when the diagnostic delay was less than $48 \mathrm{~h}$, subacute when the diagnostic was made between two days and one month after the onset of symptoms and chronic if the diagnostic delay was superior to one month. Details on the anticoagulant treatment were also collected, including type of treatment, duration and the targeted International Normalized Ratio (INR).

CVT have been related to many risk factors [4], whose presence was registered on our case series whenever affected a patient concomitant to the CVT. We also gathered information on the thrombophilia tests conducted on each case, usually: factor V Leiden 
mutation (G1691A), factor II mutation (G20210A), protein C, protein S and antithrombin III deficiencies and homocysteine levels. Anemia was considered a risk factor when the hemoglobin levels were $<10 \mathrm{~g} / \mathrm{dL}$.

Regarding APS, clinical information was gathered on criteria and non-criteria APS manifestations according to Sapporo and Sydney classifications [16-19] and on thrombotic and obstetric manifestations that took place before, simultaneously or after the CVT. All information was obtained from medical reports.

The aPL profile of every patient was registered carefully: isotype, titer and the standard used by the laboratory. Patients were classified as having primary APS or APS associated to another disease. SLE was defined by the classification criteria that were available at the moment $[20,21]$.

We gathered medical information on the outcomes and follow-up, taking into account the type of sequelae if present, and assessing the degree of neurologic handicap with the modified Rankin Scale (mRS) [22] at hospital discharge, after 6 months and after one year (Table 1).

Table 1. Modified Rankin Scale (mRS).

\begin{tabular}{cc}
\hline 0 & No symptoms \\
1 & No significant disability, despite symptoms; able to perform usual duties and activities \\
2 & Slight disability; unable to perform all previous activities but able to look after own \\
affairs without assistance
\end{tabular}

According to the mRS a year after the CVT episode, patients were classified into three prognostic groups: complete recovery (mRS 0-1), partial recovery with maintained autonomy (mRS 2), dependency (mRS 3-5) and deceased (mRS 6). After reviewing followup medical reports, data was also collected on APS manifestations, SLE manifestations and pregnancy.

Data from our descriptive retrospective observational series were analyzed in terms of percentage, mean and range. The statistical differences between our series and the cases from the literature were tested with the Mann-Whitney test (quantitative variables) and the Khi-2 test (qualitative variables). All tests were bilateral and took into account a $p$ value $<0.05$. The statistical analysis was performed using SPSS software.

\section{Results}

\subsection{Cerebral Vein Thrombosis}

Twenty-seven patients were included in our retrospective series: 14 from Hôpital Pitié-Salpêtrière, 10 from Hôpital Lariboisière, and 3 from Hospital Clínic. The first case of CVT registered took place in December 1985. Most of them were women (22 patients; female/male ratio, 4.4/1) with a median age of 35.7 years (range 16-70) at the time of the CVT episode. The main characteristics of the CVT are described in Table 2. 
Table 2. CVT characteristics. This table gathers the main information about the characteristics of the CVT, the initial treatment used and the clinical status at discharge, evaluated by mRS. Abbreviations: OC, oral contraceptives; PC deficit, protein C deficit; CS, corticosteroids; PS deficit, protein S deficit; $\mathrm{HH}$, hyperhomocysteinemia; Leiden (het), heterozygous factor V Leiden mutation; NR, not reported; FD, focal deficit; ICHT, intracranial hypertension; AMS, altered mental status; GCS, Glasgow Coma Scale; RTS, right transverse sinus; LTS, left transverse sinus; SSS, superior sagittal sinus; SS, straight sinus; RSS, right sigmoid sinus; LSS, left sigmoid sinus; Jug, jugular vein; CV, cortical veins; VI, venous infarction; PB, parenchymal bleeding; SAH, subarachnoid hemorrhage; VKA, vitamin K antagonists; IVIG, intravenous immunoglobulins; AE, antiepileptic treatment; Acet., acetazolamide.

\begin{tabular}{|c|c|c|c|c|c|c|c|c|c|}
\hline \multicolumn{2}{|c|}{$\begin{array}{l}\text { Patient } n \text {, } \\
\text { Sex, Age }\end{array}$} & \multirow{2}{*}{$\begin{array}{c}\text { APS } \\
\text { Classif. } \\
\text { SLE }\end{array}$} & \multirow{2}{*}{$\begin{array}{c}\text { Risk Factors } \\
\text { OC }\end{array}$} & \multirow{2}{*}{$\begin{array}{l}\text { Symptoms } \\
\text { Headache }\end{array}$} & \multirow{2}{*}{$\begin{array}{c}\begin{array}{c}\text { Diagnostic } \\
\text { Delay }\end{array} \\
7 \text { day }\end{array}$} & \multirow{2}{*}{$\begin{array}{c}\begin{array}{c}\text { Thrombosed } \\
\text { Sinus }\end{array} \\
\text { RTS }\end{array}$} & \multirow{2}{*}{$\begin{array}{c}\text { CNS } \\
\text { Complications } \\
-\end{array}$} & \multirow{2}{*}{$\begin{array}{c}\text { Treatment } \\
\text { VKA }\end{array}$} & \multirow{2}{*}{$\begin{array}{c}\mathrm{mRS} \\
1\end{array}$} \\
\hline 1 & F28 & & & & & & & & \\
\hline 2 & F31 & Primary & - & Headache, FD & 16 day & LTS & $\begin{array}{l}\text { Cerebellar VI } \\
\text { (bilateral) }\end{array}$ & $\begin{array}{c}\text { VKA + } \\
\text { antiplatelet }\end{array}$ & 1 \\
\hline 3 & F29 & Primary & Anemia & Headache, FD & 30 day & LTS & - & VKA & 1 \\
\hline 4 & F51 & Primary & $\begin{array}{l}\text { PC deficit, } \\
\text { Anemia }\end{array}$ & $\begin{array}{c}\text { Epileptic } \\
\text { status-GCS }<9\end{array}$ & 4 day & LTS, SSS & $\begin{array}{c}\text { PB (bilateral), } \\
\text { SAH }\end{array}$ & $\begin{array}{l}\text { VKA, IVIG, } \\
\text { AE }\end{array}$ & 4 \\
\hline 5 & F53 & SLE & Sinusitis, CS & Headache & 6 day & RTS, RSS & - & NR & 0 \\
\hline 6 & M43 & ET & $\begin{array}{l}\text { Local infection, } \\
\text { thrombocytosis }\end{array}$ & FD, Seizures & NR & NR & NR & VKA & NR \\
\hline 7 & F20 & SLE/SSc & CS & $\begin{array}{l}\text { Headache, } \\
\text { ICHT }\end{array}$ & NR & $\begin{array}{l}\text { RTS, LTS, } \\
\text { LSS, Jug }\end{array}$ & - & VKA, Acet. & 1 \\
\hline 8 & F34 & Primary & Postpartum & $\begin{array}{l}\text { Headache, FD, } \\
\text { seizures, ICHT }\end{array}$ & 1 day & $\begin{array}{c}\text { RTS, LTS, } \\
\text { SSS, SS, Jug }\end{array}$ & - & VKA, AE & 1 \\
\hline 9 & F44 & Primary & After surgery & Headache & NR & RTS, LTS, SSS & SAH (bilateral) & VKA & 1 \\
\hline 10 & F51 & Sjögren & Sinusitis & Headache & 4 day & $\mathrm{CV}$ & PB & VKA, AE & 0 \\
\hline 11 & M33 & Primary & - & Headache, FD & 3 day & $\mathrm{CV}$ & VI & VKA & 1 \\
\hline 12 & F24 & Primary & Sinusitis & Headache & 1 day & LTS, LSS, Jug & - & VKA & 1 \\
\hline 13 & F23 & Primary & - & Headache & 30 day & RTS, RSS, Jug & - & VKA, Acet. & 1 \\
\hline 14 & F41 & SLE & OC & Headache & 15 day & LTS & Cerebellar VI & VKA & 1 \\
\hline 15 & F43 & Primary & OC, PS deficit & Headache & 8 day & LTS, SSS & SAH & VKA & 1 \\
\hline 16 & M23 & SLE & - & $\begin{array}{l}\text { Headache, } \\
\text { ICHT }\end{array}$ & 48 day & $\begin{array}{c}\text { RTS, SSS, Jug, } \\
\text { CV }\end{array}$ & - & VKA & 1 \\
\hline 17 & F20 & Primary & $\mathrm{OC}, \mathrm{HH}$ & $\begin{array}{l}\text { Headache, FD, } \\
\text { Seizures, AMS }\end{array}$ & NR & $\begin{array}{c}\text { RTS, LTS, } \\
\text { SSS, SS }\end{array}$ & PB (bilateral) & VKA & 1 \\
\hline 18 & F70 & ET & - & $\begin{array}{c}\text { Headache, FD, } \\
\text { AMS }\end{array}$ & 7 day & LTS, SSS, SS & VI (bilateral) & VKA & 1 \\
\hline 19 & F39 & Primary & OC & $\begin{array}{l}\text { Headache, } \\
\text { ICHT }\end{array}$ & 3 day & LTS, LSS, Jug & - & VKA & 0 \\
\hline 20 & F40 & Primary & $\begin{array}{l}\text { OC, local } \\
\text { infection }\end{array}$ & $\begin{array}{c}\text { Headache, } \\
\text { Seizures, AMS }\end{array}$ & 1 day & SSS & $\begin{array}{l}\text { Bleeding } \\
\text { infarction } \\
\text { (bilateral) }\end{array}$ & VKA & 1 \\
\hline 21 & F16 & Primary & Local infection & Headache & 7 day & LTS & - & VKA & 0 \\
\hline 22 & F23 & Primary & OC & Headache & NR & RTS, SSS & - & VKA & 0 \\
\hline 23 & F32 & Primary & - & $\begin{array}{l}\text { Headache, } \\
\text { AMS }\end{array}$ & 5 day & LTS, Jug & $\mathrm{PB}, \mathrm{SAH}$ & VKA, IVIG & 1 \\
\hline 24 & M36 & SLE & - & Headache & 1185 day & RSS & - & VKA & 1 \\
\hline 25 & F16 & Primary & - & $\begin{array}{l}\text { Headache, } \\
\text { AMS }\end{array}$ & 10 day & LTS & $\begin{array}{l}\text { Bleeding } \\
\text { infarction }\end{array}$ & CS & 1 \\
\hline 26 & F38 & Primary & $\begin{array}{l}\text { OC, Leiden } \\
\text { (het) }\end{array}$ & Headache, FD & 3 day & LTS, LSS, Jug & PB & VKA & 0 \\
\hline 27 & M64 & Primary & 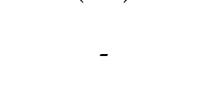 & $\begin{array}{c}\text { Headache, } \\
\text { Seizures, } \\
\text { AMS-GCS < } 9\end{array}$ & 3 day & SSS & PB (bilateral) & VKA & 4 \\
\hline
\end{tabular}

Taking into account the time between the onset of symptoms and the moment when the diagnosis of CVT was made, the majority of patients had a subacute clinical presentation (15 patients), on four cases the clinical picture was considered chronic and on three cases, acute. There was no information on 5 patients on the medical reports concerning the onset of the clinical picture.

The most common symptom at presentation of the CVT was headache, affecting 24 of the 27 patients $(88.9 \%)$ and it was the only symptom in 11 cases $(40.7 \%)$. A focal neurologic deficiency was noted on 8 patients (29.6\%): four motor deficiencies, 3 sensitive deficiencies, 3 patients with aphasia and one patient with cerebellum symptoms. Six patients had epileptic seizures, one of them went into epileptic status at admission. Three patients had 
and impaired level of consciousness ( 2 of them with Glasgow Coma Scale below 9 points). In addition, drowsiness was remarked in 2 patients and another 2 patients showed signs of confusion. Fundoscopy was performed in 10 patients, identifying signs of intracranial hypertension in three of them.

To diagnose CVT, a combination of imaging techniques was performed in half of patients (12 out of 25) including both CT scan (with or without iv contrast) and MRI (with or without angiography). There was a lack of information on this procedure in two patients. Four patients were diagnosed by MRI alone, CT scan with iv contrast alone was performed in 4 patients. An extended CVT was identified in 15 patients (57.7\%), whereas 9 patients had thrombosis in an isolated venous sinus, two patients had only involvement of the cortical veins and in one case the location of the CVT was not recorded. The most frequently thrombosed venous sinus was the left transverse sinus (16 cases, 59\%), followed by the superior sagittal sinus (10 cases, 37\%), the right transverse sinus (9 cases, 33\%), the left and right sigmoid sinuses (4 and 3 cases, $15 \%$ and $11 \%$, respectively) and the straight sinus ( 3 cases, 11\%). On 8 patients, the thrombosis was observed to involve the jugular vein as well. Furthermore, over half of the patients had intra- or extra-parenchymal complications (15 patients, 57.7\%): bleeding was found in 9 patients (6 parenchymal hemorrhages, 3 subarachnoid hemorrhages) and six patients had venous infarction (two of them were hemorrhagic). Complications observed on the central nervous system imaging techniques were bilateral in seven cases.

Another risk factor for CVT was identified in 18 patients $(66.7 \%)$; the most frequent one was the use of oral contraceptives (8 patients), followed by local infections (6 patients). Eighteen patients $(66.7 \%)$ had at least one additional risk factor besides APS and seven patients $(25.9 \%)$ had two or more risk factors besides APS.

Almost every patient was treated with low molecular weight heparin (LMWH) or unfractioned heparin (UFH) initially, switching to vitamin $\mathrm{K}$ antagonists (VKA) after a few days; only one patient was treated with corticosteroids (in 1985). No patients were treated with immunosuppressive drugs. In addition, two patients received acetazolamide for intracranial hypertension, two patients received antiepileptic drugs and two patients were treated with intravenous immunoglobulins due to thrombocytopenia (both of them had primary APS). When VKA were initiated, the targeted INR was between 2 and 3 in 14 patients (between 2.5 and 3 for two of them) and between 2.5 and 3.5 in 9 patients (between 3 and 3.5 in seven cases). The information on the targeted INR was missing in three patients.

Mean time until hospital discharge was 15.5 days (range $0-57$ days). At discharge, the mRS was 0 in 6 patients, 1 in 18 patients and 4 in 2 patients (mean mRS, 1). No patient died. Grouped in three categories, most of the patients (24) had a good clinical status at discharge with a mRS of $0-1$, no patients had a mSR of 2 and two patients were impaired for normal activities with mRS 3-5.

\subsection{Antiphospholipid Syndrome}

In our series, eighteen patients had primary APS, whereas APS was associated to SLE in 6 patients (one of them overlapped with systemic sclerosis), to essential thrombocytosis in 2 patients and to Sjögren's syndrome in 1 patient. At the time of the CVT, one patient had a SLE flare. Regarding the classification criteria, 9 patients were diagnosed with Sapporo criteria. Reviewing the antibodies profile performed, all patients diagnosed under Sapporo criteria fulfilled the Sydney criteria.

A cerebral vein thrombosis was the first manifestation of APS in 20 out of 27 patients in our series (74.07\%). At the time of the CVT episode, only two patients presented with a concomitant thrombosis in another venous territory: a deep vein thrombosis (DVT) and a pulmonary thromboembolism. Seven patients had non-criteria manifestations previous to the CVT or simultaneously: 4 had thrombocytopenia, 2 had mitral valvulopathy and one had livedo racemosa. None of the registered patients in our series presented as a catastrophic APS. The characteristics of the APS in our series are described on Table 3. 
Table 3. APS characteristics. This table gathers the main information about the APS characteristics. It is noted whether it was primary APS or associated with another disease, as well as the criteria set used at diagnosis. Based on the antibodies, patients were classified into the following categories: $\mathrm{I}$, more than one laboratory criteria present (any combination); $\mathrm{II}_{\mathrm{a}}$, LA present alone; $\mathrm{II}_{\mathrm{b}}$, aCL present alone; $\mathrm{II}_{\mathrm{c}}$, anti- $\beta_{2}$-glycoprotein-I present alone. Abbreviations: $\mathrm{F}$, female; $\mathrm{M}$, male; SLE, systemic lupus erythematosus; ET, essential thrombocytosis; SSc, systemic sclerosis; DVT, deep vein thrombosis; UL, upper limbs; LL, lower limbs; PE, pulmonary embolism.

\begin{tabular}{|c|c|c|c|c|c|c|c|c|c|}
\hline \multicolumn{2}{|c|}{$\begin{array}{l}\text { Patient } n \\
\text { Sex, Age }\end{array}$} & \multirow{2}{*}{$\begin{array}{c}\text { APS } \\
\text { Classif. } \\
\text { SLE }\end{array}$} & \multirow{2}{*}{$\begin{array}{c}\text { APS } \\
\text { Criteria } \\
\text { Sapporo }\end{array}$} & \multirow{2}{*}{$\begin{array}{c}\text { APS } \\
\text { Antibodies } \\
\begin{array}{c}\text { I-LA, aCL } \\
\text { IgG }\end{array}\end{array}$} & \multirow{2}{*}{$\begin{array}{c}\text { CVT as APS First } \\
\text { Manifestation }\end{array}$} & \multirow{2}{*}{$\begin{array}{c}\text { Concomitant } \\
\text { Thromboses }\end{array}$} & \multirow{2}{*}{$\begin{array}{c}\text { Previous } \\
\text { Thrombotic } \\
\text { Manifestations }\end{array}$} & \multirow{2}{*}{$\begin{array}{c}\begin{array}{c}\text { Previous } \\
\text { Obstetrical } \\
\text { Manifestations }\end{array} \\
-\end{array}$} & \multirow{2}{*}{$\begin{array}{c}\begin{array}{c}\text { Non-Criteria } \\
\text { Manifestations }\end{array} \\
\text { Mitral valvulopathy }\end{array}$} \\
\hline 1 & F28 & & & & & & & & \\
\hline 2 & F31 & Primary & Sapporo & $\mathrm{II}_{\mathrm{b}}-\mathrm{IgG}$ & No & - & Splenic infarction & $\begin{array}{c}\text { Stillbirth (24 } \\
\text { weeks), placental } \\
\text { insufficiency } \\
2 \text { miscarriages }\end{array}$ & - \\
\hline 3 & $\mathrm{~F} 29$ & Primary & Sydney & $\mathrm{II}_{\mathrm{c}}$ & Yes & - & - & - & - \\
\hline 4 & F51 & Primary & Sapporo & $\mathrm{II}_{\mathrm{b}}-\mathrm{IgG}$ & Yes & - & - & - & Thrombocytopenia \\
\hline 5 & F53 & SLE & Sapporo & $\underset{\text { (shift) }}{\mathrm{II}_{\mathrm{b}} \text { IgM, IgG }}$ & No & - & $\begin{array}{c}\text { PE } \\
\text { Radial artery } \\
\text { thrombosis }\end{array}$ & - & Mitral valvulopathy \\
\hline 6 & M43 & ET & Sapporo & $\mathrm{II}_{\mathrm{b}}-\mathrm{IgG}$ & Yes & - & $\begin{array}{c}\text { DVT (LL, } \\
\text { asymptomatic) }\end{array}$ & - & - \\
\hline 7 & F20 & SLE/SSc & Sydney & $\mathrm{II}_{\mathrm{b}}-\mathrm{IgG}$ & Yes & - & - & - & - \\
\hline 8 & F34 & Primary & Sydney & $\mathrm{II}_{\mathrm{b}}-\mathrm{IgG}$ & Yes & - & PE & - & - \\
\hline 9 & F44 & Primary & Sydney & $\mathrm{II}_{\mathrm{b}}-\mathrm{IgG}$ & No & - & & One miscarriage & - \\
\hline 10 & F51 & Sjögren & Sydney & $\mathrm{II}_{\mathrm{c}}$ & Yes & - & - & - & - \\
\hline 11 & M33 & Primary & Sydney & $\mathrm{II}_{\mathrm{b}}-\mathrm{IgG}$ & Yes & DVT (LL) & - & - & - \\
\hline 12 & F24 & Primary & Sydney & $\mathrm{II}_{\mathrm{c}}$ & No & - & 3 DVT (LL) & - & - \\
\hline 13 & F23 & Primary & Sydney & $\mathrm{II}_{\mathrm{b}}-\mathrm{IgG}$ & No & - & & $\begin{array}{l}2 \text { miscarriages, } 2 \\
\text { stillbirths (20 } \\
\text { weeks) }\end{array}$ & Livedo racemosa \\
\hline 14 & F41 & SLE & Sapporo & $\mathrm{II}_{\mathrm{b}}-\mathrm{IgM}, \mathrm{IgG}$ & No & - & DVT (UL) + PE & 1 miscarriage & - \\
\hline 15 & F43 & Primary & Sydney & $\mathrm{II}_{\mathrm{b}}-\mathrm{IgM}$ & Yes & - & - & - & - \\
\hline 16 & M23 & SLE & Sydney & $\mathrm{II}_{\mathrm{b}}-\mathrm{IgG}$ & Yes & - & - & - & - \\
\hline 17 & F20 & Primary & Sydney & $\mathrm{II}_{\mathrm{b}}-\mathrm{IgG}$ & Yes & - & - & - & - \\
\hline 18 & F70 & ET & Sydney & $\mathrm{II}_{\mathrm{b}}-\mathrm{IgM}$ & Yes & - & - & - & - \\
\hline 19 & F39 & Primary & Sydney & $\begin{array}{c}\text { I-LA, aCL, } \\
\mathrm{a} \beta_{2} \text { GPI }\end{array}$ & Yes & - & & One miscarriage & - \\
\hline 20 & F40 & Primary & Sapporo & $\mathrm{II}_{\mathrm{b}}-\mathrm{IgM}$ & Yes & - & - & - & - \\
\hline 21 & F16 & Primary & Sydney & $\begin{array}{l}\mathrm{I}-\mathrm{aCL}, \\
\mathrm{a} \beta_{2} \mathrm{GPI}\end{array}$ & Yes & - & - & - & Thrombocytopenia \\
\hline 22 & $\mathrm{~F} 23$ & Primary & Sydney & $\mathrm{II}_{\mathrm{b}}-\mathrm{IgG}$ & Yes & - & - & - & - \\
\hline 23 & F32 & Primary & Sydney & $\mathrm{II}_{\mathrm{a}}$ & Yes & - & - & - & Thrombocytopenia \\
\hline 24 & M36 & SLE & Sydney & $\mathrm{II}_{\mathrm{a}}^{\mathrm{a}}$ & No & - & PE & - & -1 \\
\hline 25 & F16 & Primary & Sapporo & I-LA, aCL & Yes & - & - & - & Thrombocytopenia \\
\hline 26 & F38 & Primary & Sydney & I-LA, aCL & Yes & - & - & - & - \\
\hline 27 & M64 & Primary & Sapporo & $\mathrm{II}_{\mathrm{a}}$ & Yes & PE & - & - & - \\
\hline
\end{tabular}

\subsection{Follow Up}

Mean time of follow-up was 66.8 months (range, 1-289 months). Anticoagulant treatment with VKA was maintained during follow-up in 21 patients, although in one case it was stopped after 6 years due to repeated falls. VKA were given in five patients during six months and then stopped and one patient did not receive anticoagulant treatment until 8 years after the CVT episode, when he presented DVT.

Main characteristics of follow-up and outcomes are described in Table 4. During follow-up, many patients underwent neuroimaging control tests and detailed information was available in 20 patients: ten of them had a partial repermeabilisation of the CVT, complete repermeabilisation was observed on 7 patients and the cerebral vein occlusion was persistent in 3 patients. None of the patients had a new CVT during follow-up. 
Table 4. Evolution of CVT patients during follow up. This table gathers the main information about the evolution of CVT patients during follow up. Abbreviations: NR, not reported; CS, corticosteroids; SLE, systemic lupus erythematosus; ET, essential thrombocytosis; SSc, systemic sclerosis; DVT, deep vein thrombosis; UL, upper limbs; LL, lower limbs; PE, pulmonary embolism; CVA, cerebrovascular accident; mSR, modified Rankin Scale.

\begin{tabular}{|c|c|c|c|c|c|c|c|c|c|c|}
\hline \multicolumn{2}{|c|}{$\begin{array}{l}\text { Patient } n \\
\text { Sex, Age }\end{array}$} & \multirow{2}{*}{$\begin{array}{c}\text { APS } \\
\text { Classif. } \\
\text { SLE }\end{array}$} & \multirow{2}{*}{$\begin{array}{c}\text { Months of } \\
\text { Follow-Up }\end{array}$} & \multirow{2}{*}{$\begin{array}{l}\text { INR } \\
3-3.5\end{array}$} & \multirow{2}{*}{$\begin{array}{c}\begin{array}{c}\text { Treatment } \\
\text { Duration }\end{array} \\
\text { Long-term }\end{array}$} & \multirow{2}{*}{$\begin{array}{l}\text { Neuroimaging } \\
\text { Partial reperm. }\end{array}$} & \multirow{2}{*}{$\begin{array}{c}\text { Thrombosis and } \\
\text { Hemorrhages }\end{array}$} & \multirow{2}{*}{$\begin{array}{c}\text { Sequelae } \\
-\end{array}$} & \multirow{2}{*}{$\begin{array}{c}\text { mRS } \\
6 \text { Months } \\
1\end{array}$} & \multirow{2}{*}{$\begin{array}{c}\text { mRS } \\
12 \text { Months } \\
0\end{array}$} \\
\hline 1 & $\mathrm{~F} 28$ & & & & & & & & & \\
\hline 2 & F31 & Primary & 82 & $3-3.5$ & Long-term & Complete reperm. & LL hematoma & Headache & 1 & 0 \\
\hline 3 & $\mathrm{~F} 29$ & Primary & 38 & $3-3.5$ & Long-term & NR & - & Headache & 1 & 1 \\
\hline 4 & F51 & Primary & 91 & $3-3.5$ & 6 years & Partial reperm. & - & Seizures & 2 & 2 \\
\hline 5 & F53 & SLE & 20 & $3-3.5$ & Long-term & $\begin{array}{l}\text { Persistent } \\
\text { thrombosis }\end{array}$ & - & 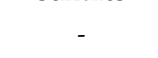 & 1 & 0 \\
\hline 6 & M43 & ET & 289 & NR & 5 months & NR & - & Seizures & 0 & 0 \\
\hline 7 & F20 & SLE/SSc & 45 & $3-3.5$ & Long-term & Partial reperm. & - & Headache & 1 & 0 \\
\hline 8 & F34 & Primary & 78 & $2.5-3$ & Long-term & Complete reperm. & - & Headache & 1 & 1 \\
\hline 9 & F44 & Primary & 53 & $2-3$ & Long-term & NR & - & NR & NR & NR \\
\hline 10 & F51 & Sjögren & 54 & NR & 7 months & $\begin{array}{l}\text { Persistent } \\
\text { thrombosis }\end{array}$ & - & - & 0 & 0 \\
\hline 11 & M33 & Primary & 12 & $2-3.5$ & Long-term & Partial reperm. & - & - & 0 & 0 \\
\hline 12 & F24 & Primary & 26 & $2-3$ & Long-term & Partial reperm. & - & - & 0 & 0 \\
\hline 13 & $\mathrm{~F} 23$ & Primary & 13 & $2-3$ & Long-term & Partial reperm. & - & Headache & 1 & 1 \\
\hline 14 & F41 & SLE & 1 & $2.5-3.5$ & Long-term & NR & $\begin{array}{l}\text { CVA (Sylvian). } \\
\text { SAH }\end{array}$ & $\begin{array}{c}\text { Seizures, } \\
\text { cognitive } \\
\text { disturbances }\end{array}$ & NR & 1 \\
\hline 15 & F43 & Primary & 37 & $2-3$ & Long-term & Complete reperm. & LL hematoma & Headache & 1 & 0 \\
\hline 16 & M23 & SLE & 19 & $2-3$ & Long-term & Partial reperm. & 20. & $\begin{array}{l}\text { Headache, } \\
\text { seizures }\end{array}$ & 1 & 0 \\
\hline 17 & F20 & Primary & 24 & $2.5-$ & Long-term & Partial reperm. & - & $\begin{array}{l}\text { Headache, } \\
\text { seizures }\end{array}$ & 1 & 1 \\
\hline 18 & F70 & ET & 48 & $2-3$ & Long-term & Complete reperm. & - & - & 1 & 0 \\
\hline 19 & F39 & Primary & 91 & $2-3$ & 6 months & Partial reperm. & - & - & 0 & 0 \\
\hline 20 & F40 & Primary & 146 & $2-3$ & Long-term & Complete reperm. & - & - & 0 & 0 \\
\hline 21 & F16 & Primary & 1 & $3-3.5$ & Long-term & NR & - & - & NR & NR \\
\hline 22 & $\mathrm{~F} 23$ & Primary & 117 & NR & 6 months & Partial reperm. & - & $\begin{array}{c}\text { Dural fistula } \\
\text { type I }\end{array}$ & 0 & 0 \\
\hline 23 & F32 & Primary & 17 & $2-3$ & Long-term & Partial reperm. & $\begin{array}{c}\text { Parenchymal } \\
\text { hematoma }\end{array}$ & $\begin{array}{l}\text { Headache, } \\
\text { cognitive } \\
\text { disturbances }\end{array}$ & 1 & 1 \\
\hline 24 & M36 & SLE & 7 & $2-3$ & Long-term & NR & - & - & 0 & 0 \\
\hline 25 & F16 & Primary & 170 & (CS) & (CS) & $\begin{array}{l}\text { Persistent } \\
\text { thrombosis }\end{array}$ & DVT (LL) & Headache & 1 & 1 \\
\hline 26 & F38 & Primary & 109 & $2-3$ & Long-term & Complete reperm. & - & - & 0 & 0 \\
\hline 27 & M64 & Primary & 90 & $2-3$ & 6 months & NR & $\begin{array}{c}\text { DVT (LL, } 4 \text { times), } \\
\text { PE }\end{array}$ & $\begin{array}{l}\text { Focal deficit, } \\
\text { seizures }\end{array}$ & 4 & 4 \\
\hline
\end{tabular}

Over half of the patients (15) suffered from diverse sequelae due to the CVT, the most common problem being headaches of variable intensity in ten cases. In six cases patients suffered from seizures, both focal and generalized. Two patients complained of cognitive disturbances, one developed a dural fistula type I that produced tinnitus and resolved spontaneously and one patient remained with hemiplegia and dysarthria (this patient suffered from diverse complications due to his neurological deficit, that lead to his death seven years after the CVT episode). At six months of follow-up, the mRS score was 0 in 9 patients, mRS 1 in 13 patients, mRS 2 in 1 patient and mRS 4 in 1 patient, with a mean mRS score of 0.79 . It was not possible to obtain detailed information from the medical records in 3 patients. Grouped into three categories, most of the patients (22; 82\%) had a good clinical status at 6 months with a mRS of $0-1$, only one patient had a mSR of 2 and one patient was impaired for normal activities with mRS 3-5. After one year of follow-up, the mRS score was 0 in 16 patients, mRS 1 in 7 patients, $\mathrm{mRS} 2$ in 1 patient and mRS 4 in 1 patient, with a mean mRS score of 0.59 . It was not possible to obtain detailed information from the medical records in two patients. Grouped into three categories, most of the patients $(23 ; 92 \%)$ had a good clinical status at one year with a mRS of $0-1$, only one patient had a mSR of 2 and one patient was impaired for normal activities with mRS 3-5.

During follow-up, seven patients (28\%) suffered new thrombosis and/or hemorrhages. There were 8 episodes of thrombosis in four patients (most of them DVT), one case of stroke and one transient ischemic attack. Three episodes happened when the patient was not taking VKA, three under VKA medication but with a low INR (below 2) and one case when the patient was taking only aspirin. Another patient had a thrombosis while taking 
VKA but there was no detailed information on the INR level at the time of the thrombosis. On the other side, five patients had hemorrhages: three were major bleedings [23] (one subarachnoid hemorrhage, one parenchymal bleeding and one psoas hematoma) and two were hematomas on the legs. Only one case had a documented high INR and in two patients detailed data was missing.

In our series, 14 of the 22 women were on a reproductive age. During the follow-up 5 pregnancies took place, from which four gave birth to healthy babies and only one had a stillbirth on second trimester.

\subsection{Review of the Literature}

Two hundred sixty-three articles were obtained after the Medline search. Fifteen were excluded due to language. Ninety-one articles were not related to APS or CVT, 79 articles were dismissed because of diverse reasons (pediatric cases, general reviews). In 29 articles there was not enough retrievable information or were not available. Finally, 14 articles were included through review of the references of the selected articles, for a total of 63 included articles. From those, 86 cases of CVT in APS patients were retrieved.

CVT cases in APS patients published in the literature affected predominantly young women (72\% of women) with a mean age at the time of the CVT of 30.5 years (range 13-68). The most frequent forms of clinical presentation were acute $(50 \%)$ and subacute $(42 \%)$, with a mean diagnostic delay of 13 days (median 3, range 1-240). A chronic presentation was observed in $8 \%$ of cases. Headaches were the most frequent symptom, reported in $74 \%$ of published cases. Intracranial hypertension and the presence of a focal deficiency at admission had the same incidence (43\%) and seizures (both focal and generalized) affected almost one third of the patients (33\%). Twenty-one percent of the patients had an altered mental status and/or GCS $<9$ at admission.

CVT was located in the lateral venous system (transverse sinuses, sigmoid sinuses) in $69 \%$ of patients, involved the superior sagittal sinus in $60 \%$ of patients and the straight sinus and deep venous system in $10 \%$ of patients. Cortical veins were thrombosed in $14 \%$ of cases. The majority of patients $(60 \%)$ had an extensive thrombosis that involved more than one sinus.

By the time of hospital discharge, most patients had a complete resolution of the clinical picture or with mild symptoms remaining (mRS $0-1$ in $73 \%$ of patients). Two patients had partial recovery with maintained autonomy (mRS score of 2 in $6 \%$ of patients) and 6 patients (11\%) had a variable degree of disability (mRS 3-5). Five patients died during hospital admission (10\%).

Besides APS, an additional risk factor was identified in over a half of the patients (64\%): pregnancy or postpartum in 35\% and oral contraceptives in $16 \%$ of the women in reproductive age, thrombophilia in $15 \%$ and only $5 \%$ of patients had a local infection.

Most patients had a primary APS (79\%), only 13\% were reported as APS associated to SLE and 7\% associated to other diseases. Three patients had catastrophic APS.

Previous manifestations of APS were reported in $40 \%$ of patients: $21 \%$ of patients had had a previous thrombotic event, $4 \%$ had non-criteria manifestations and $32 \%$ of women in a reproductive age reported previous obstetric manifestations. No previous arterial thromboses were reported. The development of the CVT lead to APS diagnosis in the majority of patients $(86 \%)$.

As for the aPL profile, $69 \%$ of patients had a single positive antibody, $26 \%$ were double positive and 5\% were triple positive. The most frequently found antibody was aCL (66\%), followed by LA (56\%) and a $\beta_{2}$ GPI (11\%).

The detailed clinical characteristics of the CVT cases gathered from the literature are described in Table 5. We compare the characteristics of our series and the series of the literature on Table 6. 


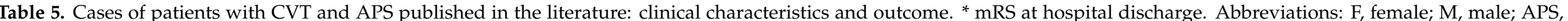

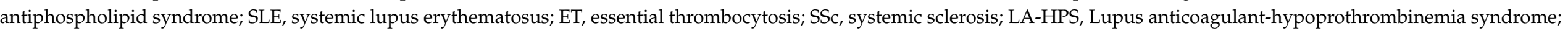

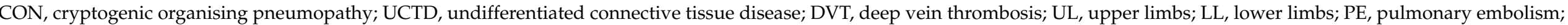

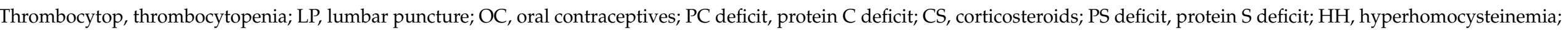

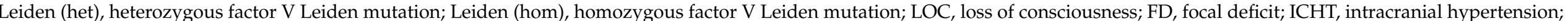

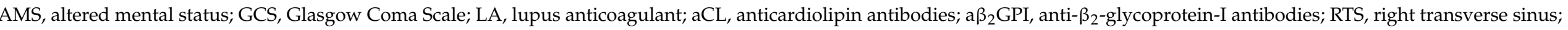

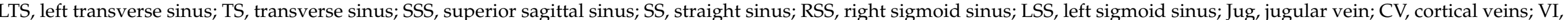

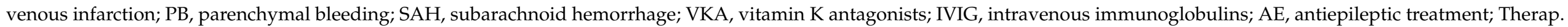
$\mathrm{LMWH}$, therapeutic low molecular weight heparin; Therap. UFH, therapeutic unfractioned heparin; Acet., acetazolamide; mSR, modified Rankin Scale; NR, not reported.

\begin{tabular}{|c|c|c|c|c|c|c|c|c|c|c|}
\hline Authors & Sex, Age & Diagnosis & $\begin{array}{c}\text { Previous APS } \\
\text { Manifestations }\end{array}$ & $\begin{array}{l}\text { Risk Factors for } \\
\text { CVT }\end{array}$ & CVT Symptoms & $\begin{array}{c}\text { APS } \\
\text { Antibodies }\end{array}$ & Thrombosis & $\begin{array}{c}\text { CNS } \\
\text { Complications } \\
\end{array}$ & Treatment & $\mathrm{mRS}$ * \\
\hline Feki et al. [24] & F36 & $\begin{array}{c}\text { APS } \\
\text { LA-HPS }\end{array}$ & Miscarriages & factor II $(37 \%)$. & $\begin{array}{c}\text { Headache }(2 \text { weeks }), \\
\text { FD, seizure, transient } \\
\text { LOC }\end{array}$ & LA, aCL IgG & SSS, CV & $\begin{array}{l}\text { Subdural } \\
\text { hemorrhage }\end{array}$ & $\mathrm{CS}, \mathrm{AE}$, heparin, VKA & NR \\
\hline \multirow{3}{*}{ Shlebak [25] } & $\mathrm{F}(20-29)$ & APS & PE (2) & $\begin{array}{l}\text { OC, obesity } \\
\text { smoker }\end{array}$ & Headache & LA & TS & - & Therap. LMWH & 0 \\
\hline & $\mathrm{F}(20-29)$ & APS & - & OC & Headache (1 week) & $\begin{array}{l}\text { LA, aCL IgG, } \\
\mathrm{a} \beta_{2} \text { GPI IgG }\end{array}$ & $\begin{array}{l}\text { TS, Sigmoid } \\
\text { sinus }\end{array}$ & - & $\begin{array}{l}\text { Therap. LMWH, then } \\
\text { VKA }\end{array}$ & 0 \\
\hline & $\mathrm{M}(30-39)$ & APS & - & Smoker & Headache, ICHT & LA, a $\beta_{2}$ GPI IgG & TS & - & $\begin{array}{l}\text { Therap. LMWH, then } \\
\text { VKA }\end{array}$ & 0 \\
\hline Ho et al. [26] & F50 & $\begin{array}{l}\text { Secondary APS } \\
\text { (Sjögren) }\end{array}$ & - & - & Headache (1 day) & LA & LTS & - & $\begin{array}{c}\text { Therap. LMWH, then } \\
\text { VKA }\end{array}$ & NR \\
\hline $\begin{array}{l}\text { Mahale et al. } \\
\quad \text { [27] }\end{array}$ & F25 & APS & Miscarriages (2) & $\begin{array}{c}\text { Pregnancy } \\
\text { (miscarriage } 5 \\
\text { day prior CVT) }\end{array}$ & $\begin{array}{l}\text { Headache, ICHT, } \\
\text { Seizures, GCS }<9\end{array}$ & $\begin{array}{l}\mathrm{LA}, \mathrm{aCL} \operatorname{IgG} \\
\text { and IgM }\end{array}$ & LTS, LSS, Jug & $\begin{array}{c}\text { Vertebral and } \\
\text { basilar artery } \\
\text { thrombosis }\end{array}$ & $\begin{array}{l}\text { Heparin, antiplatelet, } \\
\text { mannitol }\end{array}$ & 6 \\
\hline $\begin{array}{l}\text { Behrendt et al. } \\
\text { [28] }\end{array}$ & F35 & APS & - & $\begin{array}{l}\text { Sinusitis, } \\
\text { mastoiditis, } \\
\text { contraception } \\
\text { ring }\end{array}$ & $\begin{array}{c}\text { Headache ( } 3 \text { weeks), } \\
\text { ICHT, FD (abducens } \\
\text { palsy), AMS }\end{array}$ & $\begin{array}{c}\text { LA, aCL IgG } \\
\text { and IgM, } \\
\mathrm{a} \beta_{2} \text { GPI IgG and } \\
\text { IgM }\end{array}$ & SSS, RTS & ( & $\begin{array}{c}\text { NFH, then VKA } \\
\text { Acetaz., } \\
\text { ventriculo-peritoneal } \\
\text { shunt }\end{array}$ & NR \\
\hline $\begin{array}{l}\text { Pelegrina } \\
\text { Molina et al. } \\
\text { [29] }\end{array}$ & F16 & APS & - & - & $\begin{array}{l}\text { Headache (1 week), } \\
\text { ICHT }\end{array}$ & $\begin{array}{l}\text { LA, aCL IgG, } \\
\mathrm{a} \beta_{2} \text { GPI IgG }\end{array}$ & RTS, RSS & - & CS, VKA, Acet. & NR \\
\hline Tsai et al. [30] & F49 & APS & - & - & Repeated TIA (1 day) & LA & SSS & $\begin{array}{l}\text { Vasogenic } \\
\text { edema }\end{array}$ & $\begin{array}{l}\text { Therap. LMWH, then } \\
\text { VKA }\end{array}$ & 0 \\
\hline Hua et al. [31] & F25 & CAPS & - & - & $\begin{array}{l}\text { Headache, neck } \\
\text { rigidity }\end{array}$ & LA, aCL & SSS & - & $\begin{array}{l}\text { CS, mannitol, IVIG, } \\
\text { LMWH }\end{array}$ & 6 \\
\hline
\end{tabular}


Table 5. Cont.

\begin{tabular}{|c|c|c|c|c|c|c|c|c|c|c|}
\hline Authors & Sex, Age & Diagnosis & $\begin{array}{l}\text { Previous APS } \\
\text { Manifestations }\end{array}$ & $\begin{array}{l}\text { Risk Factors for } \\
\text { CVT }\end{array}$ & CVT Symptoms & $\begin{array}{c}\text { APS } \\
\text { Antibodies }\end{array}$ & Thrombosis & $\begin{array}{c}\text { CNS } \\
\text { Complications }\end{array}$ & Treatment & $\mathrm{mRS}$ * \\
\hline $\begin{array}{l}\text { Hanprasertpong } \\
\text { et al. [32] }\end{array}$ & F20 & APS & - & $\begin{array}{l}\text { Pregnancy (10 } \\
\text { weeks) }\end{array}$ & $\begin{array}{l}\text { Headache, FD (left } \\
\text { hemiparesis) }\end{array}$ & LA & RTS, RSS, CV & - & $\begin{array}{l}\text { Therap. LMWH } \\
\text { (pregnancy), then VKA }\end{array}$ & 0 \\
\hline $\begin{array}{l}\text { Sakamoto et al. } \\
\text { [33] }\end{array}$ & M38 & APS & - & - & $\begin{array}{c}\text { Headache (8 weeks), } \\
\text { ICHT, FD (abducens } \\
\text { palsy) }\end{array}$ & LA, aCL & $\begin{array}{l}\text { SSS, TS, Sigmoid } \\
\text { sinus, Jug }\end{array}$ & - & $\begin{array}{l}\text { Therap. UFH, then VKA. } \\
\text { Mannitol, } \\
\text { Ventriculo-peritoneal } \\
\text { shunt }\end{array}$ & NR \\
\hline $\begin{array}{l}\text { Pendse et al. } \\
\text { [34] }\end{array}$ & F19 & CAPS & - & $\begin{array}{l}\text { Obesity (BMI } \\
\text { 42.3), multiple } \\
\text { LP }\end{array}$ & Headache (16 weeks) & LA & SSS, RTS & - & Anticoagulation & NR \\
\hline $\begin{array}{c}\text { Bonnet et al. } \\
\text { [35] }\end{array}$ & M26 & $\begin{array}{l}\text { Secondary APS } \\
\text { (Behçet) }\end{array}$ & - & 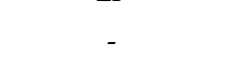 & Headache & LA & SSS, TS & - & $\begin{array}{l}\text { Therap. LMWH, then } \\
\text { VKA. CS }\end{array}$ & 0 \\
\hline $\begin{array}{l}\text { Arunkalaivanan } \\
\text { et al. [36] }\end{array}$ & F32 & APS & HELLP & Postpartum & Seizures, GCS $<9$ & aCL IgM & SSS & VI & $\begin{array}{l}\text { Therap. UFH, Therap. } \\
\text { LMWH, then VKA. AE. }\end{array}$ & 1 \\
\hline Yuen et al. [37] & F14 & $\begin{array}{l}\text { Secondary APS } \\
\text { (SLE) }\end{array}$ & - & - & Headache (4 weeks) & $\mathrm{aCL}$ & RTS, RSS, Jug & - & $\begin{array}{c}\text { Therap. LMWH, then } \\
\text { VKA. CS }\end{array}$ & 0 \\
\hline $\begin{array}{l}\text { Viswanathan } \\
\text { et al. [38] }\end{array}$ & M30 & $\begin{array}{l}\text { Sneddon } \\
\text { Syndrome }\end{array}$ & - & Smoker & Seizures, GCS < 9 & $\begin{array}{l}\text { LA, aCL IgG } \\
\text { and IgM }\end{array}$ & SSS, SS & - & $\begin{array}{l}\text { Therap. heparin, then } \\
\text { VKA. Aspirin, CS }\end{array}$ & NR \\
\hline Nagai et al. [39] & F36 & APS & $\begin{array}{l}\text { Miscarriages (2), } \\
\text { Stillbirth }\end{array}$ & $\begin{array}{l}\text { Postpartum (9 } \\
\text { day, premature) }\end{array}$ & $\begin{array}{c}\text { AMS progresses to } \\
\text { GCS < 9, ICHT, FD } \\
\text { (right hemiparesis, } \\
\text { aphasia). }\end{array}$ & $\begin{array}{l}\text { LA, aCL IgG } \\
\text { and IgM, } \\
\text { a } \beta_{2} \text { GPI }\end{array}$ & SSS, CV & - & $\begin{array}{c}\text { Mannitol, AE, CS. } \\
\text { External decompression }\end{array}$ & NR \\
\hline Kesler et al. [40] & F35 & APS & Miscarriages (3) & - & Headache, ICHT & $\begin{array}{l}\text { LA, aCL IgG } \\
\text { and IgM }\end{array}$ & SSS, RSS & - & $\begin{array}{l}\text { Therap. UFH, Therap. } \\
\text { LMWH, CS. }\end{array}$ & 0 \\
\hline Levine et al. [41] & F21 & APS & $\begin{array}{l}\text { Miscarriage, } \\
\text { DVT (LL), PE } \\
\text { Thrombocytop }\end{array}$ & Pregnancy & Headache, ICHT, FD & LA & TS & - & $\begin{array}{l}\text { Therap. LMWH, then } \\
\text { VKA. CS }\end{array}$ & NR \\
\hline & M32 & APS & Thrombocytop & - & Headache, ICHT, FD & LA & SSS, SS & - & $\begin{array}{l}\text { Therap. heparin, then } \\
\text { VKA. CS }\end{array}$ & NR \\
\hline Moreb et al. [42] & F20 & APS & - & Postpartum & Seizures, FD & LA & NR & VI & $\begin{array}{l}\text { Therap. LMWH, then } \\
\text { VKA. AE }\end{array}$ & 1 \\
\hline \multirow{3}{*}{$\begin{array}{c}\text { Vidailhet et al. } \\
\text { [43] }\end{array}$} & F24 & $\begin{array}{l}\text { Secondary APS } \\
\text { (SLE) }\end{array}$ & Stillbirth & Postpartum & $\begin{array}{c}\text { Headache, Seizures, } \\
\text { FD }\end{array}$ & $\mathrm{aCL}$ & SSS, CV & PB & $\begin{array}{c}\text { Therap. LMWH, then } \\
\text { VKA. CS }\end{array}$ & 1 \\
\hline & F31 & $\begin{array}{l}\text { Secondary APS } \\
\text { (SLE) }\end{array}$ & DVT (LL) & - & $\begin{array}{c}\text { Headache, Seizures, } \\
\text { FD }\end{array}$ & LA & SSS, TS & VI & $\begin{array}{l}\text { Therap. LMWH, then } \\
\text { VKA. CS }\end{array}$ & 1 \\
\hline & F52 & $\begin{array}{l}\text { Secondary APS } \\
\text { (SLE) }\end{array}$ & - & - & Headache, Seizures & LA & TS, Jug & NR & $\begin{array}{l}\text { Therap. LMWH, then } \\
\text { VKA. CS }\end{array}$ & 1 \\
\hline
\end{tabular}


Table 5. Cont.

\begin{tabular}{|c|c|c|c|c|c|c|c|c|c|c|}
\hline Authors & Sex, Age & Diagnosis & $\begin{array}{l}\text { Previous APS } \\
\text { Manifestations }\end{array}$ & $\begin{array}{l}\text { Risk Factors for } \\
\text { CVT }\end{array}$ & CVT Symptoms & $\begin{array}{c}\text { APS } \\
\text { Antibodies }\end{array}$ & Thrombosis & $\begin{array}{c}\text { CNS } \\
\text { Complications }\end{array}$ & Treatment & mRS * \\
\hline Mokri et al. [44] & F49 & APS & - & - & $\begin{array}{l}\text { ICHT, Headache, } \\
\text { vision impairment }\end{array}$ & aCL IgG & RTS, LTS & VI & VKA. Acet. & 1 \\
\hline \multirow{2}{*}{$\begin{array}{c}\text { Provenzale et al. } \\
\text { [45] }\end{array}$} & M62 & APS & - & - & $\begin{array}{l}\text { Headache, ICHT, } \\
\text { Seizures, FD }\end{array}$ & LA & SSS, LTS, LSS & PB, VI & Terap. heparin, then VKA & 3 \\
\hline & M25 & APS & - & - & $\begin{array}{l}\text { Headache, ICHT, } \\
\text { Seizures, FD }\end{array}$ & LA & SSS, RTS & $\mathrm{PB}, \mathrm{VI}$ & $\begin{array}{l}\text { Terap. heparin, then VKA. } \\
\text { Acet. }\end{array}$ & NR \\
\hline \multirow{2}{*}{$\begin{array}{l}\text { Boggild et al. } \\
\text { [46] }\end{array}$} & M30 & $\begin{array}{l}\text { Secondary APS } \\
\text { (Behcet) }\end{array}$ & DVT (LL) & - & Headache, ICHT & LA & SSS & - & Anticoagulation. Acet. CS & 0 \\
\hline & F42 & APS & - & After surgery & Headache, ICHT & LA & LSS & - & Antiplatelet & 0 \\
\hline $\begin{array}{c}\text { Camaiti et al. } \\
\text { [47] }\end{array}$ & F49 & APS & - & - & Headache, Seizures & $\mathrm{aCL}$ & LTS, RTS, Jug & $\mathrm{PB}$ & $\begin{array}{l}\text { Therap. heparin, then } \\
\text { VKA }\end{array}$ & NR \\
\hline Khoo et al. [48] & M51 & APS & - & - & $\begin{array}{l}\text { Headache (2 day), } \\
\text { ICHT, FD, AMS }\end{array}$ & LA & $\begin{array}{l}\text { SSS, LTS, RTS, } \\
\text { SS }\end{array}$ & Cerebral edema & $\begin{array}{l}\text { Therap. heparin, } \\
\text { Thrombolysis, VKA, CS }\end{array}$ & 0 \\
\hline Agah et al. [49] & $\mathrm{F} 44$ & APS & - & $\begin{array}{l}\text { After surgery, } \\
\text { hormonal } \\
\text { therapy }\end{array}$ & $\begin{array}{c}\text { Headache, ICHT, } \\
\text { Seizures, FD, GCS }<9\end{array}$ & LA, aCL IgG & $\begin{array}{l}\text { SSS, LTS, RTS, } \\
\text { CV }\end{array}$ & PB, VI & $\begin{array}{l}\text { Therap. heparin, } \\
\text { mannitol, AE }\end{array}$ & 6 \\
\hline \multirow[t]{2}{*}{$\begin{array}{l}\text { Silburn et al. } \\
\text { [50] }\end{array}$} & F50 & APS & DVT (LL), PE & $\begin{array}{l}\text { Hormonal } \\
\text { therapy } \\
\text { (6 weeks) }\end{array}$ & $\begin{array}{l}\text { Headache (5 days), } \\
\text { AMS, ICHT }\end{array}$ & $\mathrm{aCL}$ & SSS, LTS, SS & VI (bilateral) & Anticoagulation & 3 \\
\hline & F26 & APS & - & OC & $\begin{array}{l}\text { Headache, Seizures, } \\
\text { FD (aphasia), AMS }\end{array}$ & $\mathrm{aCL}$ & $\begin{array}{l}\text { SSS, RTS, LTS, } \\
\text { SS }\end{array}$ & VI (bilateral) & Anticoagulation & 4 \\
\hline $\begin{array}{l}\text { Ricchieri et al. } \\
\text { [51] }\end{array}$ & F30 & APS & - & $\begin{array}{c}\text { Transitory PS } \\
\text { deficit }\end{array}$ & $\begin{array}{c}\text { Seizures, FD } \\
\text { (hemiparesis), AMS }\end{array}$ & aCL IgG & SSS & $\mathrm{PB}, \mathrm{VI}$ & $\begin{array}{l}\text { Therap. heparin, then } \\
\text { VKA } \\
\text { Therap. heparin, then }\end{array}$ & 0 \\
\hline Hillier et al. [52] & $\mathrm{F} 27$ & APS & NR & PC deficit & Headache, ICHT & LA & NR & NR & $\begin{array}{l}\text { VKA. } \\
\begin{array}{c}\text { Ventriculo-peritoneal } \\
\text { shunt }\end{array}\end{array}$ & 2 \\
\hline \multirow{4}{*}{$\begin{array}{c}\text { Deschiens et al. } \\
\text { [53] }\end{array}$} & F36 & APS & NR & - & Headache, Seizures & LA & NR & NR & Mannitol, CS & 6 \\
\hline & $\mathrm{F} 25$ & $\begin{array}{l}\text { Secondary APS } \\
\text { (SLE) }\end{array}$ & - & $\begin{array}{l}\text { Leiden (het) } \\
\text { Postpartum }\end{array}$ & $\begin{array}{l}\text { Headache, Seizures, } \\
\text { FD }\end{array}$ & $\mathrm{LA}, \mathrm{aCL}$ & SSS, LTS & $\mathrm{PB}$ & $\begin{array}{c}\text { Therap. heparin, then } \\
\text { VKA. }\end{array}$ & 1 \\
\hline & F30 & APS & $\begin{array}{l}\text { Miscarriage, } \\
\text { DVT }\end{array}$ & Leiden (hom) & $\begin{array}{l}\text { Headache, FD } \\
\text { (aphasia) }\end{array}$ & $\mathrm{aCL}$ & SSS, RTS & - & $\begin{array}{c}\text { Therap. heparin, then } \\
\text { VKA. }\end{array}$ & NR \\
\hline & $\mathrm{F} 23$ & APS & - & OC & Headache, ICHT & $\mathrm{aCL}$ & SSS, RTS & - & $\begin{array}{l}\text { Therap. heparin, then } \\
\text { VKA. }\end{array}$ & NR \\
\hline
\end{tabular}


Table 5. Cont

\begin{tabular}{|c|c|c|c|c|c|c|c|c|c|c|}
\hline Authors & Sex, Age & Diagnosis & $\begin{array}{c}\text { Previous APS } \\
\text { Manifestations }\end{array}$ & $\begin{array}{l}\text { Risk Factors for } \\
\text { CVT }\end{array}$ & CVT Symptoms & $\begin{array}{c}\text { APS } \\
\text { Antibodies }\end{array}$ & Thrombosis & $\begin{array}{c}\text { CNS } \\
\text { Complications }\end{array}$ & Treatment & $\mathrm{mRS}$ * \\
\hline \multirow{7}{*}{$\begin{array}{l}\text { Carhuapoma } \\
\text { et al. [54] }\end{array}$} & F23 & NR & NR & Postpartum, OC & Seizures & $\mathrm{aCL}$ & LTS, CV & NR & Thrombolysis & NR \\
\hline & F30 & APS & NR & OC & Headache, FD & $\mathrm{aCL}$ & SSS, LTS, CV & - & Antiplatelet & NR \\
\hline & F22 & APS & - & Postpartum, OC & Headache, FD, AMS & $\mathrm{aCL}$ & LTS, CV & - & $\begin{array}{l}\text { Therap. heparin, then } \\
\text { VKA. }\end{array}$ & NR \\
\hline & F36 & APS & Miscarriage & Postpartum & Headache & $\mathrm{aCL}$ & SSS, LTS & - & $\begin{array}{l}\text { Thrombolysis. Therap. } \\
\text { heparin, then VKA. }\end{array}$ & NR \\
\hline & M19 & APS & - & - & Headache, FD & $\mathrm{aCL}$ & SSS, LTS, CV & - & $\begin{array}{l}\text { Therap. heparin, then } \\
\text { VKA. }\end{array}$ & NR \\
\hline & F33 & APS & - & Postpartum & Headache & $\mathrm{aCL}$ & RTS, Jug & - & $\begin{array}{c}\text { Therap. heparin, then } \\
\text { VKA. }\end{array}$ & NR \\
\hline & F24 & APS & Miscarriage & Postpartum & $\begin{array}{c}\text { Headache, Seizures, } \\
\text { AMS }\end{array}$ & $\mathrm{aCL}$ & SSS & - & VKA & NR \\
\hline Veilhaber et al. & F13 & APS & DVT & Otitis & Headache & $\mathrm{aCL}$ & LTS & - & NR & NR \\
\hline [55] & F16 & APS & NR & Type I PC & Headache & aCL IgG & SSS & - & NR & NR \\
\hline Kim et al. [56] & F25 & APS & NR & - & FD & $\mathrm{aCL}$ & SSS, RTS, RSS & $\mathrm{PB}, \mathrm{VI}$ & NR & NR \\
\hline Dzialo et al. [57] & M34 & APS & - & $\begin{array}{l}\text { Epidural } \\
\text { infiltration }\end{array}$ & $\begin{array}{l}\text { Headache, ICHT, } \\
\text { Seizures, FD }\end{array}$ & LA & SSS & PB, VI & $\begin{array}{c}\text { Thrombolysis. Therap. } \\
\text { heparin, then VKA. AE. } \\
\text { Mannitol }\end{array}$ & 3 \\
\hline $\begin{array}{c}\text { Marietta et al. } \\
\text { [58] }\end{array}$ & F19 & APS & DVT (LL), PE & - & Headache & LA, aCL IgG & SSS & - & $\begin{array}{c}\text { Therap. LMWH, then } \\
\text { VKA }\end{array}$ & 0 \\
\hline $\begin{array}{l}\text { Madhavan et al. } \\
\text { [60] }\end{array}$ & F25 & APS & Miscarriage & Pregnancy & ICHT, FD & $\begin{array}{l}\text { LA, aCL IgG } \\
\text { and IgM }\end{array}$ & NR & VI & $\begin{array}{l}\text { Therap. LMWH, then } \\
\text { VKA }\end{array}$ & NR \\
\hline \multirow{3}{*}{ Sareen et al. [61] } & F17 & APS & - & Anemia & ICHT & $\mathrm{aCL}$ & SSS, RTS & - & $\begin{array}{c}\text { Therap. heparin, then } \\
\text { VKA. CS }\end{array}$ & 0 \\
\hline & M20 & APS & - & - & ICHT & $\mathrm{LA}, \mathrm{aCL}$ & SSS & - & $\begin{array}{c}\text { Tharap. heparin, then } \\
\text { VKA }\end{array}$ & 0 \\
\hline & F25 & APS & - & Postpartum & ICHT & $\mathrm{aCL}$ & SSS, SS & VI (bilateral) & $\begin{array}{c}\text { Therap. heparin, then } \\
\text { VKA. CS }\end{array}$ & 0 \\
\hline $\begin{array}{c}\text { Pagnoux et al. } \\
\text { [62] }\end{array}$ & M68 & APS, Sweet S. & $\begin{array}{l}\text { Portal } \\
\text { thrombosis }\end{array}$ & $\begin{array}{l}\text { Thalidomide, } \\
\text { myelodysplastic } \\
\text { syndrome }\end{array}$ & FD (left hemiplegia) & LA, aCL IgG & SSS & VI & $\begin{array}{c}\text { Therap. heparin, then } \\
\text { VKA }\end{array}$ & 1 \\
\hline
\end{tabular}


Table 5. Cont.

\begin{tabular}{|c|c|c|c|c|c|c|c|c|c|c|}
\hline Authors & Sex, Age & Diagnosis & $\begin{array}{l}\text { Previous APS } \\
\text { Manifestations }\end{array}$ & $\begin{array}{l}\text { Risk Factors for } \\
\text { CVT }\end{array}$ & CVT Symptoms & $\begin{array}{c}\text { APS } \\
\text { Antibodies }\end{array}$ & Thrombosis & $\begin{array}{c}\text { CNS } \\
\text { Complications }\end{array}$ & Treatment & $\mathrm{mRS} *$ \\
\hline $\begin{array}{l}\text { Roldan-Molina } \\
\text { et al. [63] }\end{array}$ & F13 & $\begin{array}{l}\text { Secondary APS } \\
\text { (SLE) }\end{array}$ & - & Leiden & Headache, ICHT & LA & RTS, RSS, Jug & - & $\begin{array}{l}\text { Therap. heparin, then } \\
\text { VKA. CS }\end{array}$ & NR \\
\hline $\begin{array}{l}\text { Uthman et al. } \\
\text { [64] }\end{array}$ & F18 & $\begin{array}{l}\text { Secondary APS } \\
\text { (SLE) }\end{array}$ & - & Leiden (het) & Headache & LA & RSS, Jug & - & Anticoagulation & NR \\
\hline $\begin{array}{c}\text { Cakmak et al. } \\
{[65]}\end{array}$ & M22 & APS & - & - & Headache, Seizures & LA, aCL IgG & RTS & $\mathrm{PB}, \mathrm{VI}$ & $\begin{array}{c}\text { Therap. heparin, then } \\
\text { VKA }\end{array}$ & 1 \\
\hline $\begin{array}{c}\text { Vujovic et al. } \\
\text { [66] }\end{array}$ & F30 & APS & $\begin{array}{l}\text { Miscarriage (7), } \\
\text { premature birth } \\
\text { (1) }\end{array}$ & $\begin{array}{l}\text { Factor II mut. } \\
\text { Mastoiditis, } \\
\text { Obesity }\end{array}$ & NR & LA & RTS & - & $\begin{array}{l}\text { Therap. heparin, then } \\
\text { VKA. Acet. }\end{array}$ & NR \\
\hline \multirow{3}{*}{$\begin{array}{l}\text { Appenzeller } \\
\text { et al. [67] }\end{array}$} & $\mathrm{F} 23$ & APS & NR & - & Seizures, AMS & NR & TS & - & $\begin{array}{l}\text { Therap. heparin, then } \\
\text { VKA }\end{array}$ & 0 \\
\hline & F19 & $\begin{array}{l}\text { Secondary APS } \\
\text { (SLE) }\end{array}$ & NR & - & Headache, ICHT, FD & NR & TS, SS & VI (bilateral) & $\begin{array}{c}\text { Therap. heparin, then } \\
\text { VKA }\end{array}$ & 2 \\
\hline & F35 & APS & NR & - & $\begin{array}{l}\text { Headache, ICHT, } \\
\text { Seizures, FD }\end{array}$ & NR & SSS & VI & $\begin{array}{l}\text { Therap. heparin, then } \\
\text { VKA }\end{array}$ & 1 \\
\hline $\begin{array}{l}\text { Mutukhumar } \\
\text { et al. [68] }\end{array}$ & M38 & APS & - & $\begin{array}{l}\text { PC deficit. } \\
\text { Cranial } \\
\text { traumatism }\end{array}$ & $\begin{array}{l}\text { ICHT, FD (abducens } \\
\text { palsy) }\end{array}$ & NR & SSS & - & VKA. Acet. & 1 \\
\hline $\begin{array}{c}\text { Amberger et al. } \\
\text { [69] }\end{array}$ & F31 & APS & CVT & $\begin{array}{l}\text { Increased factor } \\
\text { VIII, OC }\end{array}$ & Headache & $\mathrm{aCL}$ & SSS, RTS & - & $\begin{array}{c}\text { Therap. heparin, then } \\
\text { VKA. }\end{array}$ & 0 \\
\hline Zeller et al. [71] & F20 & CAPS & DVT (LL) & - & Seizures, FD & LA, aCL IgM & NR & NR & $\begin{array}{l}\text { Therap. LMWH, VKA. } \\
\text { CS, AE, plasmapheresis }\end{array}$ & NR \\
\hline Varma et al. [72] & M26 & APS & - & $\begin{array}{l}\text { Anemia, } \\
\text { Nephrotic } \\
\text { Syndrome }\end{array}$ & Seizures & $\mathrm{AL}, \mathrm{aCL}$ & TS, RSS, LSS & PB (bilateral) & VKA. & NR \\
\hline Miki et al. [73] & M38 & APS & - & $\begin{array}{l}\text { Dural fistula, } \\
\text { Cranial } \\
\text { traumatism }\end{array}$ & $\begin{array}{l}\text { AMS (altered } \\
\text { behavior) }\end{array}$ & $\beta_{2} \mathrm{GPI}$ & SS & VI (bilateral) & $\begin{array}{l}\text { Anticoagulation, Fistula } \\
\text { embolization, surgery }\end{array}$ & NR \\
\hline Chen et al. [74] & M21 & APS & - & Anemia & Headache, ICHT & LA & $\begin{array}{l}\text { SSS, LTS, LSS, } \\
\text { Jug }\end{array}$ & - & $\begin{array}{l}\text { Antiplatelet, CS, } \\
\text { ciclosporin A }\end{array}$ & 0 \\
\hline
\end{tabular}


Table 5. Cont.

\begin{tabular}{|c|c|c|c|c|c|c|c|c|c|c|}
\hline Authors & Sex, Age & Diagnosis & $\begin{array}{l}\text { Previous APS } \\
\text { Manifestations }\end{array}$ & $\begin{array}{l}\text { Risk Factors for } \\
\text { CVT }\end{array}$ & CVT Symptoms & $\begin{array}{c}\text { APS } \\
\text { Antibodies }\end{array}$ & Thrombosis & $\begin{array}{c}\text { CNS } \\
\text { Complications }\end{array}$ & Treatment & $\mathrm{mRS}$ * \\
\hline Panda et al. [75] & M25 & APS & NR & - & $\begin{array}{l}\text { Headache, ICHT, } \\
\text { Seizures, FD }\end{array}$ & NR & SSS & $\mathrm{PB}, \mathrm{VI}, \mathrm{SAH}$ & $\begin{array}{l}\text { Therap. heparin, then } \\
\text { VKA. }\end{array}$ & 2 \\
\hline $\begin{array}{c}\text { Hajialilo et al. } \\
\text { [76] }\end{array}$ & F20 & $\begin{array}{l}\text { Secondary APS } \\
\text { (SLE) }\end{array}$ & - & Pregnancy & $\begin{array}{l}\text { Headache, ICHT, } \\
\text { Seizures }\end{array}$ & LA, aCL IgG & RTS, RSS & - & $\begin{array}{l}\text { Thrombolysis. Therap. } \\
\text { heparin, then VKA. CS }\end{array}$ & 0 \\
\hline \multirow[t]{2}{*}{ Demir et al. [77] } & F31 & $\begin{array}{l}\text { Secondary APS } \\
\text { (SLE) }\end{array}$ & NR & Pregnancy & $\begin{array}{l}\text { Headache, ICHT, FD } \\
\text { (III palsy) }\end{array}$ & NR & SSS, TS & - & $\begin{array}{l}\text { Therap. heparin, then } \\
\text { VKA. }\end{array}$ & 0 \\
\hline & F22 & APS & NR & Pregnancy & $\begin{array}{l}\text { Headache, ICHT, FD } \\
\text { (III palsy) }\end{array}$ & NR & SSS, SS & VI & $\begin{array}{l}\text { Therap. LMWH, then } \\
\text { VKA. }\end{array}$ & 1 \\
\hline Ikejiri et al. [78] & F18 & APS & NR & - & $\mathrm{NR}$ & $\mathrm{LA}, \mathrm{a} \beta_{2}$ GPI IgG & RTS & NR & NR & NR \\
\hline Butala et al. [79] & F37 & $\begin{array}{l}\text { Secondary APS } \\
\text { (LES) }\end{array}$ & DVT & $\begin{array}{l}\text { Cranial } \\
\text { traumatism }\end{array}$ & Headache, AMS & NR & $\begin{array}{l}\text { RTS, LTS, RSS, } \\
\text { LSS }\end{array}$ & - & Therap. heparin & NR \\
\hline $\begin{array}{c}\text { Numata et al. } \\
\text { [80] }\end{array}$ & M45 & APS & - & Tadalafil & $\begin{array}{l}\text { Headache (6 day), } \\
\text { Seizures, AMS }\end{array}$ & $\mathrm{aCL}, \mathrm{a} \beta_{2} \mathrm{GPI}$ & $\mathrm{CV}$ & VI & Therap. heparin, AE & 0 \\
\hline Hsieh et al. [81] & F67 & $\mathrm{APS}, \mathrm{CON}$ & - & $\begin{array}{l}\text { Hormonal } \\
\text { therapy }\end{array}$ & Headache & $\mathrm{a} \beta_{2}$ GPI IgM & RTS, RSS, Jug & - & $\begin{array}{l}\text { Therap. UFH, Therap. } \\
\text { LMWH, VKA. CS }\end{array}$ & NR \\
\hline $\begin{array}{l}\text { Castillo et al. } \\
\text { [82] }\end{array}$ & F19 & APS & - & OC, Otitis & $\begin{array}{c}\text { Headache (2 weeks), } \\
\text { ICHT, FD (abducens } \\
\text { palsy) }\end{array}$ & $\mathrm{LA}, \mathrm{aCL}$ & SSS, LTS, RTS & - & $\begin{array}{l}\text { Therap. heparin, then } \\
\text { VKA }\end{array}$ & 0 \\
\hline Keller et al. [83] & F36 & APS & HELLP, DVT & $\begin{array}{l}\text { Postpartum, } \\
\text { after surgery }\end{array}$ & $\begin{array}{l}\text { Headache (4 weeks), } \\
\text { ICHT, FD }\end{array}$ & $\mathrm{aCL}$ & SSS & Ictus & $\begin{array}{l}\text { Therap. LMWH, then } \\
\text { VKA. }\end{array}$ & $3-4$ \\
\hline Polster et al. [85] & F16 & APS & Preeclampsia & Postpartum & $\begin{array}{c}\text { FD (dysarthria, right } \\
\text { VII palsy and } \\
\text { hypoesthesia), } \\
\text { Seizures, ICHT }\end{array}$ & LA & $\mathrm{CV}$ & $\begin{array}{c}\text { Unstable PB, } \\
\text { Cerebral edema }\end{array}$ & $\begin{array}{c}\text { Decompressive } \\
\text { craniectomy, AE, } \\
\text { Mannitol, external } \\
\text { ventricular drain }\end{array}$ & 4 \\
\hline $\begin{array}{c}\text { Elnahry et al. } \\
\text { [86] }\end{array}$ & M21 & APS & DVT (LL) & $\mathrm{HH}$ & $\begin{array}{l}\text { Headache (4-5 weeks), } \\
\text { vision impairment, } \\
\text { ICHT, AMS } \\
\text { (confusion), fever }\end{array}$ & LA & SSS, LTS & - & $\begin{array}{l}\text { Therap. LMWH, VKA, } \\
\text { Acet. }\end{array}$ & 1 \\
\hline
\end{tabular}


Table 6. Clinical characteristics of the CVT in the literature compared to our series. The last column describes the characteristics of the APS patients presenting with a CVT (both from the literature and our series). Abbreviations: CVT, cerebral vein thrombosis; APS, antiphospholipid syndrome; ICHT, intracranial hypertension; AMS, altered mental status; GCS, Glasgow Coma Scale; mRS, modified Rankin Scale; LA, lupus anticoagulant; aCL, anticardiolipin antibodies; a ${ }_{2}$ GPI, anti- $\beta_{2}$-glycoprotein-I antibodies.

\begin{tabular}{|c|c|c|c|c|}
\hline Variables & $\begin{array}{l}\text { Retrospective Series } \\
\qquad(n=27)\end{array}$ & $\begin{array}{l}\text { Series from the Literature } \\
\qquad(n=86)\end{array}$ & $p$ & $\begin{array}{l}\text { Total CVT Cases in } \\
\text { APS Patients }(n=113)\end{array}$ \\
\hline Women & $22 / 27(82 \%)$ & $62 / 86(72 \%)$ & 0.41 & $85 / 113(75 \%)$ \\
\hline Age & 35.7 years $(16-70)$ & 30.5 years $(13-68)$ & 0.07 & 31.8 years $(13-70)$ \\
\hline \multicolumn{5}{|c|}{ Clinical presentation } \\
\hline acute & $3 / 22(14 \%)$ & $31 / 62(50 \%)$ & 0.002 & $34 / 84(40 \%)$ \\
\hline subacute & $15 / 22(68 \%)$ & $26 / 62(42 \%)$ & 0.08 & $41 / 84(49 \%)$ \\
\hline chronic & $4 / 22(18 \%)$ & $5 / 62(8 \%)$ & 0.11 & $9 / 84(11 \%)$ \\
\hline \multicolumn{5}{|c|}{ CVT risk factors } \\
\hline additional risk factors & $18 / 27(67 \%)$ & $55 / 86(64 \%)$ & 0.99 & $73 / 113(64 \%)$ \\
\hline pregnancy/postpartum & $1 / 18(6 \%)$ & $20 / 57(35 \%)$ & 0.01 & $21 / 75(28 \%)$ \\
\hline oral contraceptives & $8 / 18(44 \%)$ & $10 / 63(16 \%)$ & 0.01 & $18 / 81(22 \%)$ \\
\hline other thrombophilia & $4 / 27(15 \%)$ & $13 / 86(15 \%)$ & 0.93 & $18 / 113(16 \%)$ \\
\hline local infections & $6 / 27(22 \%)$ & $4 / 86(5 \%)$ & 0.005 & $10 / 113(9 \%)$ \\
\hline \multicolumn{5}{|c|}{ Symptoms } \\
\hline headache & $24 / 27(89 \%)$ & $64 / 86(74 \%)$ & 0.12 & $88 / 113(78 \%)$ \\
\hline ICHT & $3 / 10(30 \%)$ & $37 / 86(43 \%)$ & 0.47 & $40 / 96(42 \%)$ \\
\hline focal deficit & $8 / 27(30 \%)$ & $37 / 86(44 \%)$ & 0.22 & $45 / 113(40 \%)$ \\
\hline seizures & $6 / 27(22 \%)$ & $28 / 86(33 \%)$ & 0.32 & $34 / 113(30 \%)$ \\
\hline AMS $/$ GCS $<9$ & $7 / 27(26 \%)$ & $18 / 86(21 \%)$ & 0.53 & $25 / 113(22 \%)$ \\
\hline \multicolumn{5}{|c|}{ Cvt location } \\
\hline transverse and sigmoid sinus & $22 / 26(85 \%)$ & $55 / 80(69 \%)$ & 0.12 & $77 / 106(73 \%)$ \\
\hline superior sagittal sinus & $10 / 26(39 \%)$ & $48 / 80(60 \%)$ & 0.05 & $58 / 106(55 \%)$ \\
\hline $\begin{array}{l}\text { straight sinus and deep venous } \\
\text { cerebral system }\end{array}$ & $3 / 26(12 \%)$ & $8 / 80(10 \%)$ & 0.85 & $11 / 106(10 \%)$ \\
\hline cortical veins & $3 / 26(12 \%)$ & $11 / 80(14 \%)$ & 0.86 & $14 / 106(13 \%)$ \\
\hline extensive thrombosis & $15 / 26(58 \%)$ & $48 / 80(60 \%)$ & 0.87 & $62 / 106(58 \%)$ \\
\hline \multicolumn{5}{|c|}{$\mathrm{mRS}$ at discharge } \\
\hline mRS 0-1 & $24 / 27(89 \%)$ & $37 / 51(73 \%)$ & 0.11 & $61 / 78(78 \%)$ \\
\hline mRS 2 & $0 / 27$ & $3 / 51(6 \%)$ & 0.6 & $3 / 78(4 \%)$ \\
\hline mRS 3-5 & $2 / 27(7 \%)$ & $6 / 51(11 \%)$ & 0.68 & $8 / 78(10 \%)$ \\
\hline mRS 6 & $0 / 27$ & $5 / 51(10 \%)$ & 0.27 & $5 / 78(6 \%)$ \\
\hline Primary APS & $18 / 27(67 \%)$ & $67 / 85(79 \%)$ & 0.07 & $85 / 112(76 \%)$ \\
\hline APS-SLE & $6 / 27(22 \%)$ & $11 / 85(13 \%)$ & 0.26 & $17 / 112(15 \%)$ \\
\hline APS-other causes & $3 / 27(11 \%)$ & $6 / 85(7 \%)$ & 0.52 & $9 / 112(8 \%)$ \\
\hline \multicolumn{5}{|c|}{ Previous APS manifestations } \\
\hline total & $16 / 27(59 \%)$ & $28 / 70(40 \%)$ & 0.02 & $44 / 97(45 \%)$ \\
\hline venous thromboses & $6 / 27(22 \%)$ & $15 / 70(21 \%)$ & 0.48 & $21 / 97(22 \%)$ \\
\hline arterial thromboses & $3 / 27(11 \%)$ & $0 / 70$ & 0.03 & $3 / 97(3 \%)$ \\
\hline obstetric manifestations & $5 / 18(28 \%)$ & $15 / 46(32 \%)$ & 0.92 & $20 / 64(31 \%)$ \\
\hline non-criteria manifestations & $9 / 27(33 \%)$ & $3 / 70(4 \%)$ & $<0.001$ & $12 / 97(12 \%)$ \\
\hline Catastrophic APS & $0 / 27$ & $3 / 85(3.6 \%)$ & 0.99 & $3 / 112(2.7 \%)$ \\
\hline \multicolumn{5}{|c|}{ Immunologic characteristics } \\
\hline $\mathrm{aCL}$ & $19 / 27(70 \%)$ & $51 / 78(66 \%)$ & 0.75 & $70 / 105(67 \%)$ \\
\hline LA & $7 / 27(26 \%)$ & $44 / 78(56 \%)$ & 0.008 & $51 / 105(49 \%)$ \\
\hline $\mathrm{a} \beta_{2}$ GPI & $5 / 27(19 \%)$ & $7 / 78(9 \%)$ & 0.03 & $12 / 105(11 \%)$ \\
\hline single positive & $22 / 27(82 \%)$ & $54 / 78(69 \%)$ & 0.19 & $76 / 105(72 \%)$ \\
\hline double positive & $4 / 27(15 \%)$ & $20 / 78(26 \%)$ & 0.19 & $24 / 105(23 \%)$ \\
\hline triple positive & $1 / 27(4 \%)$ & $4 / 78(5 \%)$ & 0.22 & $5 / 105(5 \%)$ \\
\hline
\end{tabular}




\section{Discussion}

The APS is an uncommon condition characterized by a hypercoagulability state that leads to the formation of clots, both in the arterial and venous territories. Nevertheless, the cerebral venous territory is a rare location for thrombosis in these patients, as demonstrated by its low incidence in larger APS series [3]. To our knowledge, our study represents the largest series of patients with APS and CVT.

In our series, CVT related to APS affects predominantly women at a young age (32 years), similar to observations made by Carhuapoma et al. [54] and Christopher et al. [87]. The clinical picture is homogeneus, generally with a subacute onset. Even though in the series from the literature an acute onset was more frequent $(50 \%)$, the median diagnostic delay was of 3 days in the series from the literature and of 6 days in our retrospective series. Headache remained the most common symptom ( $89 \%$ of cases in our series, $74 \%$ in the series from the literature). No differences were found relating to the location of the thrombosis or the presence of CNS complications; an extensive sinus thrombosis was equally frequent. A single-center retrospective study conducted in China [88] reported similar results, with a retrospective series of 21 APS patients with CVT compared to matched non-APS controls with CVT. The APS patients were slightly younger (33 and 39 years old), but without statistical differences. Headache was the most common symptom $(90.5 \%)$, but a chronic presentation was more frequent $(52.4 \%)$. The CVT incidence in APS patients was higher than in other reports $(7.8 \%)$, as well as mortality $(15.8 \%)$, probably because it is a national referral center and more severe cases were received.

Interestingly, in our series, CVT was the first APS manifestation in almost three quarters of the patients (74\%), leading to the diagnosis of the underlying APS ( $86 \%$ in cases from the literature). These data enlighten the importance of including the search for aPL when evaluating a case of CVT. But even when an obvious cause is evident (like a local infection), we recommend screening for thrombophilia in all cases, as in our series the majority of patients had more than one risk factor for the development of CVT (67\%). Some previous studies have shown that the presence of additional risk factors increases the thrombotic risk in patients with APS [89-91]. In a prospective series of 404 APS patients, half of the patients had a combination of risk factors at the time of the first thrombosis. As for arterial thrombosis, in the RATIO study [92] patients with an ischemic stroke frequently had cardiovascular risk factors associated to the presence of aPL. These observations suggest that the presence of aPL may not be enough to induce a thrombotic event by themselves, being necessary an additional enhancing factor to trigger the thrombosis. De Groot et al. [93] considered the hypothesis of a "second hit", were the "first hit" would be the presence of the $\mathrm{aPL}$, which promote a procoagulant state, but the thrombotic event would take place when a "second hit" is added to the thrombotic risk. A later study conducted with murine models tested this hypothesis, proving that the thrombotic event only happened when there was an aggression on the vascular wall in the presence of aPL, but not in the presence of the antibodies alone [94].

We remark that the majority of patients in our series did not have a high risk profile of aPL, as 22 of them $(82 \%)$ had a single positive antibody and most of them (16 patients, $59 \%$ ) had aCL, predominantly IgG isotype (13 patients). Four patients had two positive aPL, only one patient was triple positive. This observation of a predominant low risk aPL profile supports the concept that an additional risk factor is needed for the thrombosis to happen. This is parallel to the observations in the literature, where $69 \%$ of patients had a single positive aPL (most frequently aCL), whereas only $26 \%$ were double positive and $5 \%$ triple positive. In our series, the presence of aß2GPI was significantly higher compared to the patients previously published. The difference may be because many of the published cases are previous to 2006, when the aß2GPI antibodies were included in the diagnostic criteria in the Sydney criteria revision [17].

Primary APS was the main diagnosis in our series (67\%). Sixteen patients $(59 \%)$ had previous APS manifestations, most of them DVT, which was statistically different from the series of published cases $(40 \%)$. Only one patient was under treatment with VKA and 
LDA when the CVT occurred (patient number 2). Interestingly, in our series three patients had had a previous arterial thrombosis: splenic infarctus, radial artery thrombosis and amaurosis fugax. The presence of a concomitant thrombosis was low in our study (7.4\%). Seven patients had non-criteria manifestations previous to the CVT or simultaneously: 4 had thrombocytopenia, one had livedo racemosa and two had mitral valvulopathy. Globally this indicates an incidence of $25.9 \%$ of non-criteria manifestations, which differs from the $4 \%$ found in the literature (only three patients had thrombocytopenia; no other non-criteria manifestations were published). Nevertheless, the patients in our series were admitted to referral centers for APS, which may have been more prone to detect and report the mentioned non-thrombotic manifestations. None of the patients in our series developed catastrophic APS, whereas 3 cases were described in the literature; no significant differences were found between both series.

In our series, only four patients had a new thrombosis (14.8\%) during follow-up and none of them was a CVT, which is consistent with previous publications. In the Euro-Phospholipid project 10-year period review of 1000 patients [95], 16.6\% of patients developed thrombotic events during the first 5-year period, mainly strokes $(5.3 \%)$ and transient ischemic attacks (4.7\%). In a single center cohort of APS patients followed from 2003 to 2013, the overall rate of recurrent thrombosis was 16.9\% despite antithrombotic treatment [96]. Bazzan et al. [97] reported a recurrence rate of 7.5/100 patient years in the first 5 years after the first thrombotic event and identified diabetes, inherited thrombophilia and anticoagulation withdrawal as independent risk factors for thrombosis recurrence. As for CVT, in larger studies the recurrence of CVT was between $2.2 \%$ and $4.4 \%$ [98] and after discontinuation of anticoagulation, a rate of 0.53 per 100 person-years has been reported [99]. Male gender and the presence of polycythaemia/thrombocythaemia seem to be independent risk factors for a higher risk of recurrence of CVT [100].

During follow-up, the mRS at 6 and 12 months remained favorable, and a disappearance of the remaining symptoms was observed, as many patients with a mRS score of 1 at six months after the CVT (48.1\%) were evaluated with a mRS score of 0 at 12 months (59.3\%). The mean mRS at six months was 0.79 and at 12 months, 0.52 . However, the two patients with a more serious condition due to the CVT had little or no improvement, as one remained with mRS 4 and had several complications over the years after the CVT, and the other one improved to an mRS of 2, with significant impact of the CVT sequelae on the daily basis. This is similar to the data from the ISCVT study [4], where about $80 \%$ of the patients made a complete recovery. On the series from the literature, five patients died during the hospital admission for the CVT, one due to catastrophic APS, another had a concomitant stroke (basilar artery), another due to ICHT, another due to infectious complications and in one case there was no specific information. These results are consistent with the predictors of death or dependence identified in the ISCVT study [4]: age over 37 years, male sex, coma, mental status disorder, hemorrhage on admission CT scan, thrombosis of the deep cerebral venous system, central nervous system infection, and cancer.

As for the treatment, the vast majority of patients were treated with anticoagulants (mostly heparin initially, later changed to oral anticoagulants). In our retrospective series, one patient was treated only with corticosteroids (in 1985, and she had CNS bleeding and concomitant thrombocytopenia). During follow-up, VKA was given long-term except in 5 cases, in which VKA was stopped after 6 months due to low risk aPL profile in 3 patients (single positive), two of them treated with LDA. None of those three had recurrences or other thromboses. The patients treated with anticoagulation had a good clinical evolution even though at admission many presented different forms of intracranial bleeding, which is consistent with the ISCVT study [4], where about $40 \%$ of patients had a hemorrhagic infarct even before anticoagulant treatment was started. The most recent guidelines from the European Stroke Organization on cerebral venous thrombosis [98] recommend initial treatment with LWMH or UFH when a fast reversal of anticoagulation may be needed (e.g., for neurosurgical intervention); followed by oral anticoagulants (AVK). The authors could not provide a recommendation on thrombolysis for CVT patients, but suggested not 
using it in patients with low pre-treatment risk of poor outcome [101]. Canhao et al. [102] conducted a systematic review of the literature regarding the use of thrombolytic therapy (both local and systemically administered) in CVT patients, their review suggests that thrombolytics seem to be reasonably safe in these patients. Even so, it is not possible to establish the efficacy of the thrombolytic treatment, so the authors recommend to consign it to critically ill patients non responsive to standard optimal therapy. Siddiqui et al. [103] reviewed the literature for CVT cases treated with mechanical thrombectomy with or without intrasinus thrombolysis, with similar results, as it seems reasonably safe, but there was not enough data to assess efficacy. Endovascular treatment (EVT) of severe CVT was evaluated in a multicenter randomized clinical trial [104], in which EVT along with standard medical care did not appear to be superior to medical care alone. Nonetheless, it was terminated because of futility in a pre-planned interim analyses, so the small sample size does not allow for subgroup analyses that could point to specific benefits (for instance, for patients in a coma due to CVT). In our series of APS patients with CVT, thrombolysis was used only in four patients published in the literature and in none from our retrospective series, which does not allow us to extract any conclusion.

Our study has several limitations due to its retrospective nature, as for many patients we were not able to retrieve any missing data not previously recorded in the medical reports and there is a marked variability in the follow-up time for each patient, so probably we are missing information from the patient's evolution and, consequently, overestimating the prognosis. As for the review of the literature, a publication bias may have affected the available clinical cases since observations with good results tend to be more easily selected and accepted for publication to the detriment of cases with worse outcome. On that point, we shall remark that the CVT was the first APS manifestation in the majority of our patients and they globally had a good prognosis, perhaps overestimated because more critically ill patients are less frequently published and sometimes the promptness of a rapidly progressing complication stands in the way of a complete clinical research for the underlying cause.

\section{Conclusions}

To our knowledge, our study is the largest and most complete CVT series in APS patients published to date, providing a unique point of view in this rare thrombotic manifestation, that in many cases was the first APS manifestation. When compared to the published CVT cases in APS patients, the clinical picture is homogeneous. The differences found between the two series (arterial thrombosis, non-criteria manifestations, presence of aß2GPI antibody) probably are due to the specialized approach in the three referral hospitals and the fact that many cases from the literature were prior to 2006 (inclusion of $\mathrm{a} \beta_{2}$ GPI as APS criteria).

Our results support the concept that CVT in APS patients is quite similar to CVT by other causes, but they are slightly younger. Interestingly, APS patients presenting with a CVT had an aPL profile of low thrombotic risk and additional CVT risk factors were frequently found, which remarks the hypothesis of a triggering factor that affects a susceptible subject, provoking the final thrombotic event. However, some patients relapsed during follow-up with thrombosis in other locations, which is suggestive of a true underlying thrombophilia. In a patient with CVT, it is essential to search for aPL antibodies, as its presence implies a different therapeutic approach and clinical management in follow-up.

Author Contributions: Conceptualization, Z.A. and A.M.; methodology, Z.A. and A.M.; validation, Z.A., A.M., J.A., I.C., F.C.-A., M.H., J.H., D.W., A.J.-L. and R.C.; formal analysis, J.A. and A.J.-L.; investigation, Z.A., A.M., J.A., I.C., F.C.-A., M.H., J.H., D.W., A.J.-L. and R.C.; writing-original draft preparation, J.A. and A.J.-L.; writing-review and editing Z.A., A.M., J.A., I.C., F.C.-A., M.H., J.H., D.W., A.J.-L. and R.C.; supervision, Z.A. All authors have read and agreed to the published version of the manuscript.

Funding: This research received no external funding. 
Informed Consent Statement: Informed consent was obtained from all subjects involved in the study.

Data Availability Statement: Data available on request due to privacy restrictions.

Conflicts of Interest: The authors declare no conflict of interest.

\section{References}

1. Cervera, R.; Khamashta, M.A.; Shoenfeld, Y.; Camps, M.T.; Jacobsen, S.; Kiss, E.; Zeher, M.M.; Tincani, A.; Kontopoulou-Griva, I.; Galeazzi, M.; et al. Morbidity and mortality in the antiphospholipid syndrome during a 5-year period: A multicentre prospective study of 1000 patients. Ann. Rheum. Dis. 2009, 68, 1428-1432. [CrossRef] [PubMed]

2. Hughes, G.R. Thrombosis, abortion, cerebral disease, and the lupus anticoagulant. Br. Med. J. (Clin. Res. Ed). 1983, 287, 1088-1089. [CrossRef] [PubMed]

3. Cervera, R.; Piette, J.-C.; Font, J.; Khamashta, M.A.; Shoenfeld, Y.; Camps, M.T.; Jacobsen, S.; Lakos, G.; Tincani, A.; KontopoulouGriva, I.; et al. Antiphospholipid syndrome: Clinical and immunologic manifestations and patterns of disease expression in a cohort of 1,000 patients. Arthritis Rheum. 2002, 46, 1019-1027. [CrossRef] [PubMed]

4. Ferro, J.M. Prognosis of Cerebral Vein and Dural Sinus Thrombosis: Results of the International Study on Cerebral Vein and Dural Sinus Thrombosis (ISCVT). Stroke 2004, 35, 664-670. [CrossRef] [PubMed]

5. Ferro, J.M.; Canhao, P. Cerebral venous sinus thrombosis: Update on diagnosis and management. Curr. Cardiol. Rep. 2014, 16, 523. [CrossRef]

6. Coutinho, J.M.; Zuurbier, S.M.; Aramideh, M.; Stam, J. The Incidence of Cerebral Venous Thrombosis: A Cross-Sectional Study. Stroke. 2012, 43, 3375-3377. [CrossRef]

7. Stam, J. Thrombosis of the cerebral veins and sinuses. N. Engl. J. Med. 2005, 352, 1791-1798. [CrossRef]

8. Alami, B.; Boujraf, S.; Quenum, L.; Oudrhiri, A.; Alaoui Lamrani, M.Y.; Haloua, M.; Boubbou, M.; Maâroufi, M. La thrombose veineuse cérébrale: Aspects clinico-radiologiques, à propos d'une série de 62 cas [Cerebral venous thrombosis: Clinical and radiological features, about 62 cases]. J. Med. Vasc. 2019, 44, 387-399. [CrossRef]

9. Napon, C.; Diallo, O.; Kanyala, E.; Kabore, J. Les thromboses veineuses cérébrales en milieu hospitalier à Ouagadougou (Burkina Faso). Rev. Neurol. 2010, 166, 433-437. [CrossRef]

10. Breteau, G.; Mounier-Vehier, F.; Godefroy, O.; Gauvrit, J.Y.; Mackowiak-Cordoliani, M.A.; Girot, M.; Bertheloot, D.; Hénon, H.; Lucas, C.; Leclerc, X.; et al. Cerebral venous thrombosis 3-year clinical outcome in 55 consecutive patients. J. Neurol. 2003, 250, 29-35. [CrossRef]

11. Masuhr, F.; Mehraein, S.; Einhäupl, K. Cerebral venous and sinus thrombosis. J. Neurol. 2004, 251, 11-23. [CrossRef] [PubMed]

12. Martinelli, I.; Battaglioli, T.; Pedotti, P.; Cattaneo, M.; Mannucci, P.M. Hyperhomocystinemia in cerebral vein thrombosis. Blood 2003, 102, 1363-1366. [CrossRef]

13. Coutinho, J.M.; Ferro, J.M.; Canhão, P.; Barinagarrementeria, F.; Cantú, C.; Bousser, M.G.; Stam, J. Cerebral venous and sinus thrombosis in women. Stroke 2009, 40, 2356-2361. [CrossRef] [PubMed]

14. Bonneville, F. Imaging of cerebral venous thrombosis. Diagn. Interv. Imaging 2014, 95, 1145-1150. [CrossRef] [PubMed]

15. Dmytriw, A.A.; Song, J.S.A.; Yu, E.; Poon, C.S. Cerebral venous thrombosis: State of the art diagnosis and management. Neuroradiology 2018, 60, 669-685. [CrossRef]

16. Wilson, W.A.; Gharavi, A.E.; Koike, T.; Lockshin, M.D.; Branch, D.W.; Piette, J.C.; Brey, R.; Derksen, R.; Harris, E.N.; Hughes, G.R.; et al. International consensus statement on preliminary classification criteria for definite antiphospholipid syndrome: Report of an international workshop. Arthritis Rheum. 1999, 42, 1309-1311. [CrossRef]

17. Miyakis, S.; Lockshin, M.D.; Atsumi, T.; Branch, D.W.; Brey, R.L.; Cervera, R.; De Groot, P.G.; Koike, T.; Meroni, P.L.; Reber, G.; et al. International consensus statement on an update of the classification criteria for definite antiphospholipid syndrome (APS). J. Thromb. Haemost. 2006, 4, 295-306. [CrossRef]

18. Cervera, R.; Tektonidou, M.; Espinosa, G.; Cabral, A.; Gonzalez, E.; Erkan, D.; Vadya, S.; Adrogué, H.E.; Solomon, M.; ZandmanGoddard, G.; et al. Task Force on Catastrophic Antiphospholipid Syndrome (APS) and Non-criteria APS Manifestations (I): Catastrophic APS, APS nephropathy and heart valve lesions. Lupus 2011, 20, 165-173. [CrossRef]

19. Cervera, R.; Tektonidou, M.; Espinosa, G.; Cabral, A.; Gonzalez, E.; Erkan, D.; Vadya, S.; Adrogué, H.E.; Solomon, M.; ZandmanGoddard, G.; et al. Task Force on Catastrophic Antiphospholipid Syndrome (APS) and Non-criteria APS Manifestations (II): Thrombocytopenia and skin manifestations. Lupus 2011, 20, 174-181. [CrossRef]

20. Tan, E.M.; Cohen, A.S.; Fries, J.F.; Masi, A.T.; McShane, D.J.; Rothfield, N.F.; Schaller, J.G.; Talal, N.; Winchester, R.J. The 1982 revised criteria for the classification of systemic lupus erythematosus. Arthritis Rheum. 1982, 25, 1271-1277. [CrossRef]

21. Petri, M.; Orbai, A.M.; Alarcon, G.S.; Gordon, C.; Merrill, J.T.; Fortin, P.R.; Bruce, I.N.; Isenberg, D.; Wallace, D.J.; Nived, O.; et al. Derivation and validation of the Systemic Lupus International Collaborating Clinics classification criteria for systemic lupus erythematosus. Arthritis Rheum. 2012, 64, 2677-2686. [CrossRef]

22. Van Swieten, J.C.; Koudstaal, P.J.; Visser, M.C.; Schouten, H.J.; van Gijn, J. Interobserver agreement for the assessment of handicap in stroke patients. Stroke 1988, 19, 604-607. [CrossRef] 
23. Schulman, S.; Kearon, C.; on behalf of the subcommittee on control of anticoagulation of the Scientific and Standardization committee of the International Society on Thrombosis and Haemostasis. Definition of major bleeding in clinical investigations of antihemostatic medicinal products in non-surgical patients. J. Thromb. Haemost. 2005, 3, 692-694. [CrossRef] [PubMed]

24. Feki, N.B.; Zayet, S.; Ben Ghorbel, I.; Houman, M.H. Lupus anticoagulant-hypoprothrombinemia syndrome presenting with co-existing cerebral venous thrombosis and subdural hemorrhage. J. Mal. Vasc. 2016, 41, 403-406. [CrossRef] [PubMed]

25. Shlebak, A. Antiphospholipid syndrome presenting as cerebral venous sinus thrombosis: A case series and a review. J. Clin. Pathol. 2016, 69, 337-343. [CrossRef] [PubMed]

26. Ho, T.H.; Hsu, Y.W.; Wang, C.W.; Lee, J.T.; Ting, C.H.; Yang, F.C. Cerebral Venous Sinus Thrombosis in A Patient with Sjögren's Syndrome with Atypical Antibodies: A Case Report. Acta Neurol. Taiwan 2016, 25, 65-69.

27. Mahale, R.R.; Mehta, A.; Javali, M.; Srinivasa, R. Co-ocurrence of basilar artery and cerebral venous sinus thrombosis in antiphospholipid antibody syndrome. Neurol. India 2014, 62, 552-554. [CrossRef]

28. Behrendt, M.H.; Lohmann, C.P.; Klopfer, M. Bilateral papilledema, unilateral loss of vision and abducens nerve palsy. Ophthalmologe. 2013, 111, 560-564. [CrossRef] [PubMed]

29. Pelegrina Molina, J.; Barrero Hernández, F.J.; Callejas Rubio, J.L.; Anaya Alaminos, R.; Ortego Centeno, N. Neuroretinitis and intracranial venous thrombosis in antiphospholipid syndrome. Neurologia 2014, 29, 316-318. [CrossRef]

30. Tsai, C.L.; Hueng, D.Y.; Tsao, W.L.; Lin, J.C. Cerebral venous sinus thrombosis as an initial manifestation of primary antiphospholipid syndrome. Am. J. Emerg. Med. 2013, 31, 888.e1-888.e3. [CrossRef] [PubMed]

31. Hua, R.; Wu, H.; Zhang, X.W.; Sun, Y.W. Probable catastrophic antiphospholipid syndrome complicated with primary sclerosing cholangitis. J. Dig. Dis. 2012, 13, 601-603. [CrossRef]

32. Hanprasertpong, T.; Hanprasertpong, J.; Riabroi, K. Cerebral venous sinus thrombosis in early pregnancy: An unusual presentation of primary antiphospholipid syndrome. J. Obstet. Gynaecol. Res. 2009, 35, 1125-1128. [CrossRef] [PubMed]

33. Sakamoto, S.; Akutsu, K.; Kawase, K.; Takada, T.; Seyama, H.; Takahashi, J.; Miyamoto, S.; Nonogi, H.; Takeshita, S. Simultaneous Presentations of Deep Vein Thrombosis and Cerebral Sinus Thrombosis in a Case of Primary Antiphospholipid Syndrome. Angiology 2008, 59, 765-768. [CrossRef] [PubMed]

34. Pendse, S.; Bilyk, J.R.; Olivia, C.; Biousse, V. Now you see it. Surv. Ophthalmol. 2008, 53, 177-182. [CrossRef]

35. Bonnet, F.; Debruxelles, S.; Dubourguet, L.; Guérin, V.; Rambeloarisoa, J.; Morlat, P.; Baste, J.C.; Beylot, J. Lupus anticoagulant and Behçet's disease: Increase of vascular risk? Rev. Med. Intern. 2004, 25, 835-836. [CrossRef]

36. Arunkalaivanan, A.S.; Barrington, J.W. Late puerperal sagittal sinus thrombosis associated with primary antiphospholipid antibody syndrome. J. Obstet. Gynaecol. 2002, 22, 682. [CrossRef]

37. Yuen, S.Y.; Lau, K.F.; Steinberg, A.W.; Grattan-Smith, P.J.; Hodson, E.M. Intracranial venous thrombosis and pulmonary embolism with antiphospholipid syndrome in systemic lupus erythematosus. J. Paediatr. Child Health 2001, 37, 405-408. [CrossRef]

38. Viswanathan, K.N.; Anandan, S.; Sreenivas, S.; Kumar, K.S.; Raman, S. A 30-year-old man with stroke and skin lesions. Postgrad. Med. J. 2000, 76, 49-51. [CrossRef] [PubMed]

39. Nagai, S.; Horie, Y.; Akai, T.; Takeda, S.; Takaku, A. Superior sagittal sinus thrombosis associated with primary antiphospholipid syndrome-Case report. Neurol. Med. -Chir. 1998, 38, 34-39. [CrossRef]

40. Kesler, A.; Pomeranz, I.S.; Huberman, M.; Novis, B.; Kott, E. Cerebral venous thrombosis and chronic active hepatitis as part of the antiphospholipid syndrome. Postgrad. Med. J. 1996, 72, 690-692. [CrossRef]

41. Levine, S.R.; Kieran, S.; Puzio, K.; Feit, H.; Patel, S.C.; Welch, K.M. Cerebral venous thrombosis with lupus anticoagulants. Report of two cases. Stroke 1987, 18, 801-804. [CrossRef]

42. Moreb, J.; Kitchens, C.S. Acquired functional protein S deficiency, cerebral venous thrombosis, and coumarin skin necrosis in association with antiphospholipid syndrome: Report of two cases. Am. J. Med. 1989, 87, 207-210. [CrossRef]

43. Vidailhet, M.; Piette, J.C.; Wechsler, B.; Bousser, M.G.; Brunet, P. Cerebral venous thrombosis in systemic lupus erythematosus. Stroke 1990, 21, 1226-1231. [CrossRef] [PubMed]

44. Mokri, B.; Jack, C.R., Jr.; Petty, G.W. Pseudotumor syndrome associated with cerebral venous sinus occlusion and antiphospholipid antibodies. Stroke 1993, 24, 469-472. [CrossRef] [PubMed]

45. Provenzale, J.M.; Loganbill, H.A. Dural sinus thrombosis and venous infarction associated with antiphospholipid antibodies: MR findings. J. Comput. Assist. Tomogr. 1994, 18, 719-723. [CrossRef]

46. Boggild, M.D.; Sedhev, R.V.; Fraser, D.; Heron, J.R. Cerebral venous sinus thrombosis and antiphospholipid antibodies. Postgrad. Med. J. 1995, 71, 487-489. [CrossRef] [PubMed]

47. Camaiti, A.; Del Rosso, A.; Checcucci, D.; Buggiani, A.; Federighi, G. Venous dural sinus thrombosis in a middle-aged woman with anticardiolipin antibodies. Acta Neurol. Belg. 1995, 95, 92-95.

48. Khoo, K.B.; Long, F.L.; Tuck, R.R.; Allen, R.J.; Tymms, K.E. Cerebral venous sinus thrombosis associated with the primary antiphospholipid syndrome. Resolution with local thrombolytic therapy. Med. J. Aust. 1995, 162, 30-32. [CrossRef]

49. Agah, R.; Rice, L.; Winikates, J. Fatal cerebral venous thrombosis as the initial manifestation of the antiphospholipid syndrome. Clin. Neurol. Neurosurg. 1996, 98, 189-191. [CrossRef]

50. Silburn, P.A.; Sandstrom, P.A.; Staples, C.; Mowat, P.; Boyle, R.S. Deep cerebral venous thrombosis presenting as an encephalitic illness. Postgrad. Med. J. 1996, 72, 355-357. [CrossRef]

51. Ricchieri, G.L.; Pizzolato, G.; Fabbri, M.; Patrassi, G.M.; Sartori, M.T. Cerebral and vein thrombosis, transient protein S deficiency, and anticardiolipin antibodies. Am. J. Hematol. 1996, 52, 69-70. [CrossRef] 
52. Hillier, C.E.; Collins, P.W.; Bowen, D.J.; Bowley, S.; Wiles, C.M. Inherited prothrombotic risk factors and cerebral venous thrombosis. QJM 1998, 91, 677-680. [CrossRef]

53. Deschiens, M.A.; Conard, J.; Horellou, M.H.; Ameri, A.; Preter, M.; Chedru, F.; Samama, M.M.; Bousser, M.G. Coagulation Studies, Factor V Leiden, and Anticardiolipin Antibodies in 40 Cases of Cerebral Venous Thrombosis. Stroke 1996, 27, 1724. [CrossRef]

54. Carhuapoma, J.R.; Mitsias, P.; Levine, S.R. Cerebral venous thrombosis and anticardiolipin antibodies. Stroke 1997, 28, 2363-2369. [CrossRef]

55. Vielhaber, H.; Ehrenforth, S.; Koch, H.G.; Scharrer, I.; van der Werf, N.; Nowak-Göttl, U. Cerebral venous sinus thrombosis in infancy and childhood: Role of genetic and acquired risk factors of thrombophilia. Eur. J. Pediatr. 1998, 157, 555-560. [CrossRef] [PubMed]

56. Kim, J.H.; Choi, C.G.; Choi, S.J.; Lee, H.K.; Suh, D.C. Primary antiphospholipid antibody syndrome: Neuroradiologic findings in 11 patients. Korean J. Radiol. 2000, 1, 5-10. [CrossRef]

57. Dzialo, A.F.; Black-Schaffer, R.M. Cerebral venous thrombosis in young adults: 2 Case reports. Arch. Phys. Med. Rehabil. 2001, 82, 683-688. [CrossRef] [PubMed]

58. Marietta, M.; Bertesi, M.; Simoni, L.; Castelli, I.; Cappi, C.; Torelli, G. Cerebral vein thrombosis and lupus anticoagulant antibodies. Clin. Appl. Thromb. Hemost. 2001, 7, 238. [CrossRef]

59. Kao, A.; Dlugos, D.; Hunter, J.V.; Mamula, P.; Thorarensen, O. Anticoagulation therapy in cerebral sinovenous thrombosis and ulcerative colitis in children. J. Child Neurol. 2002, 17, 479-482. [CrossRef] [PubMed]

60. Madhavan, S.; Rajesh, R.; Girija, A.S. Primary antiphospholipid antibody syndrome presenting as venous infarct and deep vein thrombosis. J. Assoc. Phys. India 2003, 51, 629-631.

61. Sareen, D.; Jain, A.; Paljor, P. Pseudotumor syndrome associated with antiphospholipid antibodies and cerebral venous sinus thrombosis. J. Assoc. Phys. India 2002, 50, 603-605.

62. Pagnoux, C.; Lutz-Zarrouk, V.; Michel, M.; Schaeffer, A.; Godeau, B. Cerebral venous thrombosis in a patient with antiphospholipid syndrome treated with thalidomide. Lupus 2004, 13, 481-482. [CrossRef] [PubMed]

63. Roldan-Molina, R.; Roman, J.; Escudero, A.; Perez-Guijo, V.; Castro, C.; Martinez, F.G.; Collantes, E. Unusual and aggressive thrombotic onset in two children with antiphospholipid-antibody syndrome and systemic lupus erythematosus. Jt. Bone Spine 2004, 71, 327-330. [CrossRef]

64. Uthman, I.; Khalil, I.; Sawaya, R.; Taher, A. Lupus anticoagulant, factor V Leiden, and methylenetetrahydrofolate reductase gene mutation in a lupus patient with cerebral venous thrombosis. Clin. Rheumatol. 2004, 23, 362-363. [CrossRef]

65. Cakmak, S.; Nighoghossian, N.; Desestret, V.; Hermier, M.; Cartalat-Carel, S.; Derex, L.; Honnorat, J.; Trouillas, P. Pulmonary embolism: An unusual complication of cerebral venous thrombosis. Neurology 2005, 65, 1136-1137. [CrossRef]

66. Vujović, S.; Zidverc, J.; Stojanović, M.; Penezić, Z.; Ivović, M.; Dukić, V.; Drezgić, M. Drospirenone in the treatment of severe premenstrual cerebral edema in a woman with antiphospholipid syndrome, lateral sinus thrombosis, situs inversus and epileptic seizures. Gynecol. Endocrinol. 2005, 21, 243-247. [CrossRef] [PubMed]

67. Appenzeller, S.; Zeller, C.B.; Annichino-Bizzachi, J.M.; Costallat, L.T.L.; Deus-Silva, L.; Voetsch, B.; Faria, A.V.; Zanardi, V.A.; Damasceno, B.P.; Cendes, F. Cerebral venous thrombosis: Influence of risk factors and imaging findings on prognosis. Clin. Neurol. Neurosurg. 2005, 107, 371-378. [CrossRef]

68. Muthukumar, N. Cerebral venous sinus thrombosis and thrombophilia presenting as pseudo-tumour syndrome following mild head injury. J. Clin. Neurosci. 2004, 11, 924-927. [CrossRef]

69. Amberger, N.; Weih, M.; Harms, L.; Valdueza, J.M. Third occurrence of cerebral venous thrombosis in a 33-year-old woman. Cerebrovasc. Dis. 2006, 21, 416-418. [CrossRef]

70. Lega, B.C.; Yoshor, D. Postoperative dural sinus thrombosis in a patient in a hypercoagulable state. Case report. J. Neurosurg. 2006, 105, 772-774. [CrossRef] [PubMed]

71. Zeller, L.; Almog, Y.; Tomer, A.; Sukenik, S.; Abu-Shakra, M. Catastrophic thromboses and severe thrombocytopenia during heparin therapy in a patient with anti-phospholipid syndrome. Clin. Rheumatol. 2006, 25, 426-429. [CrossRef] [PubMed]

72. Varma, P.P.; Khurana, H.; Hooda, A.K.; Marwaha, V.; Badwal, S. Renal thrombotic microangiopathy and cerebral venous thrombosis in a young man. Natl. Med. J. India 2007, 20, 297-299. [PubMed]

73. Miki, Y.; Tomiyama, M.; Arai, A.; Kimura, T.; Suzuki, C.; Nunomura, J.; Midorikawa, H.; Nishimura, S.; Nishijima, M.; Baba, M. Cerebral venous thrombosis with dural arteriovenous fistulas and antiphospholipid syndrome: A case report. Neurol. Sci. 2010, 31, 237-238. [CrossRef] [PubMed]

74. Chen, J.; You, X.; Qian, M. Development of cerebral venous sinus thrombosis in an aplastic anemia patient with antiphospholipid syndrome. Chin. Med. J. 2010, 123, 2486-2488.

75. Panda, S.; Prashantha, D.K.; Shankar, S.R.; Nagaraja, D. Localized convexity subarachnoid haemorrhage-a sign of early cerebral venous sinus thrombosis. Eur. J. Neurol. 2010, 17, 1249-1258. [CrossRef]

76. Hajialilo, M.; Noshad, H.; Mohammadian, R.; Khabbazi, A.R.; Daghighi, M.H.; Saleh, P. Thrombolytic therapy for cerebral vein thrombosis in antiphospholipid syndrome secondary to systemic lupus erythematosus. Iran. J. Med. Sci. 2012, 37, 58-61. [PubMed]

77. Demir, C.F.; Inci, M.F.; Ozkan, F.; Yıldız, M.; Ozdemir, H. Clinical and Radiological Management and Outcome of Pregnancies Complicated by Cerebral Venous Thrombosis: A Review of 19 Cases. J. Stroke Cerebrovasc. Dis. 2013, 22, 1252-1257. [CrossRef] 
78. Ikejiri, M.; Shindo, A.; Ii, Y.; Tomimoto, H.; Yamada, N.; Matsumoto, T.; Abe, Y.; Nakatani, K.; Nobori, T.; Wada, H. Frequent association of thrombophilia in cerebral venous sinus thrombosis. Int. J. Hematol. 2012, 95, 257-262. [CrossRef]

79. Butala, J.; Swanson, G.; Chopra, A. Catatonia as a manifestation of cerebral venous sinus thrombosis. Prim. Care Compan. CNS Disord. 2018, 20, 17102148. [CrossRef]

80. Numata, K.; Shimoda, K.; Shibata, Y.; Shioya, A.; Tokuda, Y. The Development of Cerebral Venous Thrombosis after Tadalafil Ingestion in a Patient with Antiphospholipid Syndrome. Intern. Med. 2017, 26, 1235-1237. [CrossRef]

81. Hsieh, J.; Kuzmanovic, I.; Vargas, M.I.; Momjian-Mayor, I. Cerebral venous thrombosis due to cryptogenic organising pneumopathy with antiphospholipid syndrome worsened by heparin-induced thrombocytopenia. BMJ Case Rep. 2013, 1-4. [CrossRef]

82. Castillo, I.G.; Foroozan, R.; Sergott, R.C. A Sticky Situation. Surv. Ophthalmol. 2002, 47, 491-499. [CrossRef]

83. Keller, E.; Sommer, T.; Lutterbey, G.; Schild, H.H. Koinzidenz arterieller und venöser zerebraler Thrombosen beim primären Antiphospholipid-Syndrom. Rofo 1996, 165, 300-302. [CrossRef]

84. Nyo, M.T.L.; Kalla, A.A. Thrombocytopenia and thrombosis: A double-edged sword. Clin. Rheumatol. 2014, 33, 587-590. [CrossRef] [PubMed]

85. Polster, S.P.; Lyne, S.B.; Mansour, A. Case Demonstrating the Nuances of Acute Cortical Venous Thrombosis Anticoagulation Guidelines. World Neurosurg. 2020, 139, 215-218. [CrossRef]

86. Elnahry, A.G.; Talbet, J.H.; El Mahgoub, I.R.; Elnahry, G.A. Optic Nerve Sheath Fenestration for Papilledema Due to Cerebral Venous Sinus Thrombosis Associated with Antiphospholipid Syndrome: A Case Report. Am. J. Case Rep. 2021, 24, $22:$ e930497. [CrossRef] [PubMed]

87. Christopher, R.; Nagaraja, D.; Dixit, N.S.; Narayanan, C.P. Anticardiolipin antibodies: A study in cerebral venous thrombosis. Acta Neurol. Scand. 1999, 99, 121-124. [CrossRef] [PubMed]

88. Shen, H.; Huang, X.; Fan, C. Clinical Characteristics and Management of Cerebral Venous Sinus Thrombosis in Patients With Antiphospholipid Syndrome: A Single-Center Retrospective Study. Clin. Appl. Thromb. Hemost. 2021, 27, 1076029621999104. [CrossRef] [PubMed]

89. Hansen, K.E.; Kong, D.F.; Moore, K.D.; Ortel, T.L. Risk factors associated with thrombosis in patients with antiphospholipid antibodies. J. Rheumatol. 2001, 28, 2018-2024. [PubMed]

90. Giron-Gonzalez, J.A.; del Rio, E.G.; Rodriguez, C.; Rodriguez- Martorell, J.; Serrano, A. Antiphospholipid syndrome and asymptomatic carriers of antiphospholipid antibody: Prospective analysis of 404 individuals. J. Rheumatol. 2004, 31, $1560-1567$.

91. Simantov, R.; Lo, S.K.; Salmon, J.E.; Sammaritano, L.R.; Silverstein, R.L. Factor V Leiden increases the risk of thrombosis in patients with antiphospholipid antibodies. Thromb. Res. 1996, 84, 361-365. [CrossRef]

92. Urbanus, R.T.; Siegerink, B.; Roest, M.; Rosendaal, F.R.; de Groot, P.G.; Algra, A. Antiphospholipid antibodies and risk of myocardial infarction and ischaemic stroke in young women in the RATIO study: A case-control study. Lancet Neurol. 2009, 8, 998-1005. [CrossRef]

93. De Groot, P.G.; Derksen, R.H.W.M. Pathophysiology of the antiphospholipid syndrome. J. Thromb. Haemost. 2005, 3, 1854-1860. [CrossRef]

94. Arad, A.; Proulle, V.; Furie, R.A.; Furie, B.C.; Furie, B. $\beta_{2}$-Glycoprotein-1 autoantibodies from patients with antiphospholipid syndrome are sufficient to potentiate arterial thrombus formation in a mouse model. Blood 2011, 117, 3453-3459. [CrossRef] [PubMed]

95. Cervera, R.; Serrano, R.; Pons-Estel, G.J.; Ceberio-Hualde, L.; Shoenfeld, Y.; de Ramón, E.; Buonaiuto, V.; Jacobsen, S.; Zeher, M.M.; Tarr, T.; et al.; Euro-Phospholipid Project Group (European Forum on Antiphospholipid Antibodies). Morbidity and mortality in the antiphospholipid syndrome during a 10-year period: A multicentre prospective study of 1000 patients. Ann. Rheum. Dis. 2015, 74, 1011-1018. [CrossRef]

96. Serrano, R.; Pons-Estel, G.J.; Espinosa, G.; Quintana, R.M.; Reverter, J.C.; Tassies, D.; Monteagudo, J.; Cervera, R. Long-term follow-up of antiphospholipid syndrome: Real-life experience from a single center. Lupus 2020, 29, 1050-1059. [CrossRef] [PubMed]

97. Bazzan, M.; Vaccarino, A.; Stella, S.; Sciascia, S.; Montaruli, B.; Bertero, M.T.; Carignola, R.; Roccatello, D.; Piedmont APS Consortium. Patients with antiphosholipid syndrome and thrombotic recurrences: A real world observation (the Piedmont cohort study). Lupus 2016, 25, 479-485. [CrossRef]

98. Ferro, J.M.; Bousser, M.G.; Canhão, P.; Coutinho, J.M.; Crassard, I.; Dentali, F.; di Minno, M.; Maino, A.; Martinelli, I.; Masuhr, F.; et al. for the European Stroke Organization. European Stroke Organization guideline for the diagnosis and treatment of cerebral venous thrombosis-endorsed by the European Academy of Neurology. Eur. J. Neurol. 2017, 24, 1203-1213. [CrossRef]

99. Martinelli, I.; Bucciarelli, P.; Passamonti, S.M.; Battaglioli, T.; Previtali, E.; Mannucci, P.M. Long-term evaluation of the risk of recurrence after cerebral sinus-venous thrombosis. Circulation 2010, 121, 2740-2746. [CrossRef] [PubMed]

100. Miranda, B.; Ferro, J.M.; Canhão, P.; Stam, J.; Bousser, M.G.; Barinagarrementeria, F.; Scoditti, U.; ISCVT Investigators. Venous thromboembolic events after cerebral vein thrombosis. Stroke 2010, 41, 1901-1906. [CrossRef] [PubMed]

101. Ferro, J.M.; Bacelar-Nicolau, H.; Rodrigues, T.; Bacelar-Nicolau, L.; Canhão, P.; Crassard, I.; Bousser, M.G.; Dutra, A.P.; Massaro, A.; Mackowiack-Cordiolani, M.A.; et al.; ISCVT and VENOPORT investigators. Risk score to predict the outcome of patients with cerebral vein and dural sinus thrombosis. Cerebrovasc. Dis. 2009, 28, 39-44. [CrossRef] [PubMed]

102. Canhao, P.; Falcao, F.; Ferro, J.M. Thrombolytics for cerebral sinus thrombosis: A systematic review. Cerebrovasc. Dis. 2003, 15, 159-166. [CrossRef] 
103. Siddiqui, F.M.; Dandapat, S.; Banerjee, C.; Zuurbier, S.M.; Johnson, M.; Stam, J.; Coutinho, J.M. Mechanical thrombectomy in cerebral venous thrombosis: Systematic review of 185 cases. Stroke 2015, 46, 1263-1268. [CrossRef] [PubMed]

104. Coutinho, J.M.; Zuurbier, S.M.; Bousser, M.G.; Ji, X.; Canhão, P.; Roos, Y.B.; Crassard, I.; Nunes, A.P.; Uyttenboogaart, M.; Chen, J.; TO-ACT investigators; et al. Effect of Endovascular Treatment With Medical Management vs Standard Care on Severe Cerebral Venous Thrombosis: The TO-ACT Randomized Clinical Trial. JAMA Neurol. 2020, 77, 966-973. [CrossRef] [PubMed] 